ANUARIO DE Estudios MEDIEVALES

51/2, julio-diciembre de 2021, pp. 743-779

ISSN 0066-5061

https://doi.org/10.3989/aem.2021.51.2.09

\title{
CONFLICTOS Y PLEITOS EN DOCUMENTOS NAVARROS MEDIEVALES: TIPOLOGÍA DE LOS PROCESOS Y PERSPECTIVA IDEOLÓGICA*
}

\author{
CONFLICTS AND DISPUTES IN MEDIEVAL DOCUMENTS OF NAVARRE: \\ THE TYPOLOGY OF TRIALS AND IDEOLOGICAL APPROACH
}

\author{
GuAdALupe Lopetegui SEMPERENA \\ Universidad del País Vasco \\ https://orcid.org/0000-0002-2454-4147
}

Resumen: El objetivo del presente trabajo es analizar un corpus de documentos relativos a conflictos y pleitos gestados en Navarra durante los siglos XI y XII con el fin de precisar, tanto el mecanismo de los procesos judiciales como la perspectiva ideológica que se refleja en la terminología y en la retórica discursiva. El análisis nos ha permitido establecer una tipología de los conflictos y probar que la perspectiva ideológica adoptada por los emisores de la documentación condiciona tanto la selección de los hechos narrados como la presentación de los agentes implicados en los conflictos y la justificación de los acuerdos alcanzados.

Palabras clave: conflictos; procesos judiciales; ideología; terminología; retórica discursiva.

Abstract: The aim of this paper is to analyse a corpus of documents relating to conflicts and disputes that took place in Navarre during the $11^{\text {th }}$ and $12^{\text {th }}$ centuries in order to clarify both the procedure of judicial trials and the ideological view behind the terminology and discursive rhetoric. The study has enabled us to define a typology of conflicts and to prove that the ideological approach assumed by the writers of the documents, conditions the selection of the facts reported, the characterisation of the individuals involved in the conflicts and the justification of the resolutions.

Keywords: conflicts; trials; ideology; terminology; discursive rhetoric.

\section{SUMARIO}

1. Introducción.-2. Conflictos gestionados bajo arbitraje real.-2.1. Entre señores laicos y eclesiásticos.- 2.2. Enfrentamientos protagonizados por comunidades campesinas.3. Conflictos sin intervención real.- 4. Conclusiones.- 5. Fuentes primarias.- 6. Bibliografía citada.

\footnotetext{
* Este trabajo se ha realizado en el marco del proyecto de investigación "El ejercicio del poder: espacios, agentes y escrituras (ss. XI-XV)", HAR 2017-84718-P. Por otro lado, quiero agradecer a los evaluadores de este artículo sus indicaciones y sugerencias ya que han contribuido a mejorar el resultado final.

Citation / Cómo citar este artículo: Guadalupe Lopetegui Semperena, Conflictos y pleitos en documentos navarros medievales: tipología de los procesos y perspectiva ideológica, "Anuario de Estudios Medievales" 51/2, pp. 743-779. https://doi.org/10.3989/aem.2021.51.2.09

Copyright: (C 2021 CSIC. Este es un artículo de acceso abierto distribuido bajo los términos de la licencia de uso y distribución Creative Commons Reconocimiento 4.0 Internacional (CC BY 4.0).
} 


\section{INTRODUCCIÓN ${ }^{1}$}

El objeto del presente estudio es analizar un corpus de documentos navarros medievales que contienen noticias sobre conflictos y pleitos. Más concretamente, se examinan aspectos terminológicos y discursivos con el fin de precisar tanto el funcionamiento de los procesos judiciales como los móviles ideológicos que pudieron condicionar la escritura misma del documento y la perspectiva adoptada en la narración de los hechos. Hay que destacar, además, que la mayor parte de los diplomas analizados son anteriores a la plasmación escrita de los ordenamientos jurídicos recogidos en las distintas familias de fueros y otorgados, mayoritariamente, a partir del siglo XII. En cuanto al ámbito de estudio en el que se sitúa este trabajo, cabe señalar que la resolución de conflictos y pleitos constituye un tema complejo que ha sido analizado desde los ámbitos de la historia jurídica, social y cultural ${ }^{2}$. Dentro de la producción historiográfica consagrada a esta cuestión, ocupan un lugar central los trabajos relativos a la servidumbre y al desarrollo de la estructura social feudal ya que en ellos se aborda inevitablemente la gestación y evolución de conflictos de toda índole ${ }^{3}$.

El corpus en que hemos basado el análisis está constituido por diplomas publicados en las colecciones documentales de Leire, Irache y de la catedral de Pamplona si bien a lo largo de la casuística descrita se han incluido también referencias esporádicas a documentos emilianenses o pinatenses correspondientes a la regencia de diferentes monarcas navarros con el fin de contrastar los datos ofrecidos. Así, teniendo en cuenta, sobre todo, la bibliografía relativa a situaciones de conflictividad social en documentación navarro-aragonesa $^{4}$ y las conclusiones señaladas, entre otros, por Adachi ${ }^{5}$ en relación a la

${ }^{1}$ Abreviaturas utilizadas: $\mathrm{BG}=$ Becerro Galicano digital; $\mathrm{CDCPamplona}=$ Colección diplomática de la Catedral de Pamplona; CDIrache = Colección diplomática de Irache; CSJPeña = Cartulario de San Juan de la Peña; DMLeire = Documentación medieval de Leire.

2 Sobre los mecanismos de resolución de conflictos durante el período medieval, véase: Davies, Fouracre 1986; Bossy 1983; SHMESP 2001; Brown, Górecki 2003; Billoré, Mathieu, Avignon 2012; Davies 2016, 2020. En el ámbito hispano, cabe citar el número monográfico coordinado por I. Alfonso en la revista "Hispania" con el título Desarrollo legal, prácticas judiciales y acción política en la Europa medieval, 1997 (especialmente los artículos de Salrach 1997; Alfonso 1997), Calderón Ortega 1999 y en relación al discurso judicial y su finalidad ideológico-política, Alfonso 2004, pp. 51-88. Más reciente es el monográfico dedicado a la Justicia Medieval en la revista "De Medio Aevo" 2016 (introducción general y referencias bibliográficas a cargo de Martín Prieto). Para un tratamiento amplio de los conflictos sociales durante el Medievo tanto en el ámbito hispano como en el europeo véase Monsalvo 2016.

${ }^{3}$ En lo que hace a la Navarra medieval hemos tenido en cuenta, fundamentalmente, Larrea 1998; 2006, pp. 383-409; Fortún 1993, 2005; para Navarra y Aragón, además, Laliena 2012, 2000; Adachi 2007.

${ }^{4}$ Principalmente Larrea 1998; Laliena 2012.

${ }^{5}$ Adachi 2007 . 
resolución de disputas en diplomas navarro-aragoneses del s. XI, hemos centrado nuestro interés en la documentación conservada en los centros religiosos más emblemáticos de la Navarra medieval con el fin de precisar la tipología de los procesos conservados y la perspectiva ideológica que reflejan. Más concretamente, en un espacio cronológico que se extiende desde la primera mitad del siglo XI - período en que se datan los conflictos más tempranos del corpus- hasta el término del reinado de Sancho VI a finales del s. XII, el total de documentos analizados que contienen relatos de conflictos o alusiones a algún tipo de pleito está constituido por 75 diplomas. Se trata de un corpus exiguo si lo comparamos con la cantidad de diplomas conservados en el mismo período en los condados catalanes o en los reinos de Castilla y León 6 .

La mayoría de los documentos relatan de forma más bien escueta conflictos llevados a término, bien entre alguno de los monasterios citados y señores particulares ${ }^{7}$, bien entre entidades religiosas ${ }^{8}$. Mucho menos frecuentes son los conflictos protagonizados por comunidades de campesinos ${ }^{9}$. En un porcentaje importante de los conflictos analizados (44\%) el rey interviene como mediador. Por otra parte, hay que señalar que la mayor parte de la documentación conservada relata conflictos horizontales en palabras de Salrach, es decir, enfrentamientos entre representantes de la élite dominante. En cambio, los conflictos verticales, entablados entre señores eclesiásticos o laicos con comunidades de campesinos o miembros de la baja nobleza son poco frecuentes y la perspectiva parcial, favorable a los intereses señoriales o monásticos se refleja en el relato de los hechos de forma más acentuada que en los conflictos horizontales.

En lo que hace al contenido, cabe destacar que, aunque los documentos mencionan, en general, el origen y la causa del conflicto son pocos los

${ }^{6}$ Desde el 2017 disponemos de una base de datos que reúne toda la documentación editada del norte de la península - desde Portugal hasta Cataluña- anterior al siglo XII. Ha sido editada por el CSIC (2017, Isabel Alfonso Antón y Julio Escalona) y es fruto del Proyecto de investigación "Procesos Judiciales en las sociedades medievales del norte peninsular" (PRJ) cuyo fin es "profundizar en el conocimiento de los procesos de resolución de disputas y del ejercicio de la justicia en las sociedades altomedievales del norte ibérico" (http://hdl.handle. net/10261/151329). De los diplomas recogidos (cerca de 22.000), casi un $10 \%$ contiene algún tipo de información judicial. Además, se ha publicado también recientemente una colección documental que recopila 557 escrituras sobre procesos judiciales y resolución de conflictos en los condados catalanes durante la Edad Media (Salrach, Montagut i Estragués 2018).

7 DMLeire, 52, 116, 127, 142, 146, 157, 158, 171, 194, 195, 196, 205, 219, 223, 232, 259, 265, 273, 313, 327, 348, 350; CDCPamplona, 10, 48, 132, 311, 359; CDIrache, I, 27, 63, 82.

${ }^{8}$ DMLeire, 62, 104, 131, 256, 292, 322, 342; CDCPamplona, 90, 139, 209, 250, 253, 260, $263,271,282,288,300,319,331,346,356,402,403$. Además, un considerable número de diplomas son consecuencia del largo enfrentamiento del Cabildo con el cenobio legerense por el supuesto privilegio de exención que este último defendía haber recibido del Papado y que lo liberaba de la dependencia para con el obispado de Pamplona: CDCPamplona, 323, 324, 325 , $329,335,343,344,377,379,380,385,386,396$.

${ }^{9}$ DMLeire, 50, 162, 169, 191, 278; CDIrache, 105; CDCPamplona, 256. 
que ofrecen un relato detallado del procedimiento mediante el que se solventa. Por lo demás, las fases que constituyen el proceso judicial y se deducen del relato documental son, fundamentalmente, las mismas que en otros territorios peninsulares y europeos: formación de una asamblea o concilium de notables -denominados generalmente como seniores, barones, boni homines o meliores homines- presididos por el rey o por un iudex, examen de pruebas y escucha de testimonios, juramento del encausado, orden o sentencia que emite el juez, designación de fiadores y testigos y firma del documento testimonial ${ }^{10}$. En cualquier caso, en la mayoría de los documentos analizados no se ofrecen demasiados detalles de los procesos ni se registran en estilo directo los contenidos de los juramentos pronunciados, si no es en algún caso aislado. Más bien, se concreta el origen de la querimonia en cuestión, se alude a la celebración de un iudicium y se precisan los términos de la convenientia o acuerdo con que se zanja el conflicto. Por otro lado, es preciso tener en cuenta que, al tratarse de documentación procedente de scriptoria monásticos, tanto los hechos mencionados como la imagen que se ofrece de las partes implicadas se narran desde una postura ideológica concreta. A partir de dicha perspectiva, los escribas o, más exactamente, los ordenantes de los documentos transmiten su interpretación de los hechos así como una justificación de las decisiones adoptadas.

Desde un punto de vista formal, hay que señalar que, en ocasiones, es difícil identificar a partir de la denominación del tipo diplomático qué documentos contienen relatos de pleitos y conflictos ya que formalmente algunos de ellos son presentados como actas de donaciones o confirmaciones. Sin embargo, tales "donaciones" son, en realidad, el resultado de los pactos que cierran la negociación de un conflicto previo ${ }^{11}$. Considerados en conjunto, en un $49 \%$ de los diplomas se alude explícitamente a la discordia o pleito que ha generado la escritura del documento a través de la fórmula hec est carta rememorationis seu convenientie/concordie ${ }^{12}$ o de otra expresión genérica que introduce la noticia

\footnotetext{
${ }^{10}$ Larrea distingue seis etapas en los procesos judiciales no concernientes al establecimiento de lindes territoriales. Señala además, que frente a la pervivencia de la tradición goda en algunas zonas como los condados catalanes, tal como lo prueba la presencia en ellos del Liber Iudicum, en Navarra el juramento y el recurso a la memoria de las gentes constituyen los elementos probatorios fundamentales en la etapa pre-feudal (1998, pp. 271-272). Ello no implica negar la existencia de dicha tradición goda como marco común ya que, como señala el citado historiador, el funcionamiento de la justicia local en diversas regiones del Occidente europeo revela la pervivencia de un fondo común que comparten en mayor o menor grado (ibidem, p. 276).

11 Por ejemplo, DMLeire, 50, 52, 62, 116, 291, 297, 327, 348. En DMLeire, 131, un documento falsificado en época de Sancho Ramírez y que no vamos a abordar en esta ocasión, la mención del tipo documental es intencionadamente descriptiva y compleja: "Hec est carta iudiciorum et iuracionis et preceptum donationis et confirmationis quam facio".

${ }_{12}$ DMLeire, 127, 142, 146, 171, 191, 195, 205, 259, 262, 278, 292, 313; CDCPamplona, 139, 209, 253, 260, 263, 331, 346, 356; CDIrache, 105.
} 
del conflicto ${ }^{13}$. En 23 documentos (un $28 \%$ del total), se precisa a través de la mención del tipo documental el negocio concreto estipulado por la sentencia ${ }^{14}$. Por fin, en dos diplomas no hallamos una narración de hechos asociados a un conflicto sino una mera enumeración de querellas ${ }^{15} \mathrm{y}$ cuatro más contienen meras alusiones a pleitos de los que no conocemos apenas nada ${ }^{16}$. En realidad, la utilización de estas fórmulas constituye un reflejo de la consolidación de los pactos como medio generalizado para solventar los conflictos ${ }^{17}$. En cuanto a la naturaleza de los diplomas estudiados, hay que señalar que prácticamente todos los documentos son copias realizadas entre finales del XI y los siglos XII y XIII, exceptuando un original del año 1119 (CDCPamplona, 132) ${ }^{18}$. En este sentido, queremos señalar que el hecho de contar con copias es una circunstancia que se debe tener en cuenta en la valoración del contenido ideológico de algunos documentos ya que dicho contenido corresponde, en realidad, a los intereses de la entidad eclesial en el momento en que se realizó la copia.

Al margen de estas consideraciones formales y conceptuales, el cotejo de la información contenida en los diplomas analizados con estudios basados en documentación coetánea de otros territorios permite constatar similitudes evidentes en la mecánica que preside el desarrollo de los conflictos y su resolución. De hecho, la bibliografía especializada ha subrayado la existencia de un fondo jurídico común en diversas regiones del Occidente europeo, fondo que en los reinos hispanos se plasmó en la tradición romano-visigoda. Así, teniendo en cuenta tales similitudes en la evolución de los mecanismos judiciales, nos ha parecido precisa y adaptable al ámbito navarro la periodización que a partir del examen de cartularios catalanes establece Salrach en el desarrollo y evolución de los procesos judiciales durante la Edad Media.

13 "Hec est carta" (DMLeire, 104, 265); "Sciendum vero est" (DMLeire, 327); "Cum sepius querimoniam... audissem" (CDCPamplona, 48); "Notum fieri decrevimus" (CDCPamplona, 90); "Hoc est notitia de placito" (CDCPamplona, 132); "hoc est testamentum quod ego... feci... de concordia" (CDCPamplona, 209); "Manifestum sit omnibus" (CDCPamplona, 250); "Cum pro uentilando negotio" (CDCPamplona, 271); "controversia siquidem... habita" (CDCPamplona, 282); "Inter... et... est controversia agitata" (CDCPamplona, 300), etc.

14 "Hec est carta definicionis, evacuationis siue confirmacionis" (DMLeire, 157, 165, 196, 219, 232, 350; CDCPamplona, 10); "rememoracionis siue donationis" (DMLeire, 158, 273); "hec est carta conmutacionis... pro removenda de medio discordia" (DMLeire, 322, 263); "confirmacionis et restitucionis" (DMLeire, 348), etc.

${ }^{15}$ DMLeire, 256; CDCPamplona, 107.

16 DMLeire, 223, 292, 297; CDCPamplona, 372.

17 Adachi señala que en el siglo XI es frecuente añadir al término "rememoratio" el de "convenientia" o el del negocio concreto a que da lugar el acuerdo (2007, pp. 75-77).

${ }_{18}$ Así, por ejemplo, los diplomas legerenses, que constituyen la mayor parte del corpus están contenidos en el Becerro mayor de Leire cuya elaboración se terminó prácticamente a finales del XII. Concretamente, los diplomas analizados no se consideran interpolados ni falsificados (Fortún 1993, p. 50). 
El citado investigador distingue cuatro períodos, que hemos tomado como punto de referencia para valorar los datos y la terminología de nuestro corpus, sin perder de vista los rasgos específicos que diversos medievalistas han destacado en lo que respecta al ámbito judicial en la Navarra altomedieval ${ }^{19}$.

En palabras de Salrach, los siglos IX y X constituyen en Cataluña un período definido por la pervivencia de la tradición hispano-goda, hecho que se traduce en la existencia de un sistema judicial desarrollado a través de audiencias públicas sustentadas en la autoridad de un código legal escrito (el Liber Iudicum) y la influencia de disposiciones gestadas en el entorno carolingio. Los tribunales, presididos por jueces profesionales, examinan pruebas escritas y testimonios orales; además, pueden acudir a ellos advocati o assertores. Tras una fase de transición que comprende los primeros decenios del siglo XI, desde mediados de dicho siglo y hasta finales del XII se extiende el primer feudalismo: los mecanismos jurídicos tradicionales se han "desgastado" y surgen nuevas formas de regulación de conflictos. En este amplio período la negociación y los pactos se convierten en el mecanismo de resolución fundamental, especialmente en los conflictos que tienen lugar entre miembros de la élite dominante, ya sean laicos o eclesiásticos. Cuando las disputas se producen entre elementos socialmente desiguales, la aplicación de instrumentos como las ordalías o juicios de Dios reflejan la utilización represora de los mismos en favor de la institución señorial. Por último, a finales del XII se constata un cambio tendente al restablecimiento de una justicia institucionalizada, gestionada por profesionales de la ley y basada en el derecho romano y canónico escrito $^{20}$. Aunque los límites cronológicos entre las fases enumeradas pueden variar de una zona a otra, el marco descrito lo consideramos válido para situar e interpretar los datos ofrecidos por la documentación analizada ${ }^{21}$.

\footnotetext{
${ }_{19}$ Salrach 1997, pp. 1009-1034; 2001, pp. 117-118.

${ }^{20}$ En referencia a los condados catalanes Salrach afirma que a finales del XII se empieza a imponer el derecho sabio de tradición romana y la justicia profesional (1997, p. 1041).

${ }^{21}$ De hecho, numerosos estudios subrayan el colapso o "desgaste" del sistema judicial público a lo largo del s. XI hasta mediados del s. XII (véase White 1978; Geary 1986; Collings 1986 o los trabajos de Barthélémy, Lemesle y Salrach en SHMESP 2001). Por otra parte, la bibliografía relativa a las situaciones de conflictividad social ha incidido en la importancia de aspectos diversos, tales como la importancia de la memoria colectiva como prueba testifical, la necesidad de verbalizar públicamente los acuerdos pactados o la función del ritual que acompañaba a determinados aspectos del proceso judicial. Así, por ejemplo, I. Alfonso subraya la importancia de dar un carácter público a las fases del proceso judicial: la apelación a la memoria colectiva y el examen de las pruebas ante testigos reconocidos permitía en la fase feudal construir una verdad legitimadora. Esta verdad que estaría sustentada en alianzas y dependencias vasalláticas, refleja en opinión de la investigadora "una compleja trama de intereses y relaciones sociales" que, por otro lado, pueden explicar el carácter negociado de las resoluciones adoptadas (Alfonso 1997, p. 953). Por otro lado, la práctica de las pesquisas y la preservación de los hechos a través de la memoria de los ancianos dio origen a la existencia de "archivos
} 
Por lo que hace al marco cronológico en el que se sitúa nuestro corpus, cabe señalar que a excepción de un documento (CDCPamplona, 10), el $75 \%$ de los diplomas están datados entre la segunda mitad del s. XI y la primera mitad del XII, período que correspondería a la fase feudal en la periodización anteriormente descrita ${ }^{22}$. En dicha etapa se habría producido ya una degradación de las condiciones de vida de las comunidades campesinas por medio de la imposición de censos, tributos y prestaciones, y un trato judicial cada vez más degradante ${ }^{23}$. Además, el desarrollo de las diversas formas de dominio señorial estaría relacionado con el recurso generalizado a las convenientiae, pactos que se convierten, junto con el cobro de penas pecuniarias o la toma de prendas en garantía, en el modo habitual de solucionar conflictos horizontales ${ }^{24}$. Según se desprende de la casuística reflejada en los diplomas, el procedimiento judicial presenta los mecanismos tradicionales: las partes enfrentadas buscan una solución pactada tras el examen de las pruebas, la escucha de los testimonios orales y la prestación de juramento ante una asamblea formada por boni homines. Hay que señalar que no se menciona explícitamente código legal alguno, tan solo alusiones generales a la lex terrae en contadas ocasiones. En pleitos mantenidos entre miembros de la élite eclesial sí se constata la aplicación de un procedimiento judicial asentado en la legislación canónica ${ }^{25}$. En cualquier caso, no vamos a abordar en esta ocasión el análisis de procesos judiciales entre entidades eclesiásticas que precisaron del arbitraje de instancias eclesiales superiores, ya que tales procesos están supeditados a un procedimiento jurídico específico asentado en la legislación canónica. Por tanto, en los apartados siguientes examinaremos el relato de conflictos horizontales y verticales gestionados con o sin arbitraje real entre

de conocimiento" que complementaban los documentos escritos y que es difícil aprehender a través de las escrituras (Smail 1997, p. 1050).

${ }^{22}$ Del total de diplomas que integran el corpus (75), 47 están datados entre mediados del XI y la primera mitad del XII. La mayoría de los datados en la segunda mitad del XII corresponden a pleitos entre entidades religiosas dirimidos ante un tribunal eclesial.

${ }^{23}$ Laliena 2012, pp. 79-80; Larrea 1998, pp. 376-406.

${ }^{24}$ Larrea señala que el proceso de señorialización, iniciado en Navarra a finales del reinado de Sancho el Mayor, provocó una degradación de las condiciones del campesinado a través de la imposición de "malos fueros" y de la redistribución de tierras, rentas y prestaciones de origen público en el seno de la aristocracia (1998, p. 381).

${ }^{25}$ Nos referimos a pleitos como los que entabló el obispado pamplonés con el cenobio legerense o con los obispados colindantes. Como señala Loring, "desde los tiempos de Constantino los obispos desempeñaron un importante papel en el terreno judicial" de modo que la iglesia visigoda incorporó este principio de capacidad jurídica y a partir del III Concilio de Toledo prohibió a los clérigos acudir a tribunales civiles. Las competencias judiciales de los obispos continuaron desarrollándose durante el Medievo (1989, p. 47). En cualquier caso, los pleitos entre obispos o los de estos con instituciones monásticas requieren la participación de altas instancias eclesiales y procesos legales ajustados a la legislación canónica. 
entidades religiosas o miembros de la élite dominante y señores particulares o comunidades. Los pleitos entre entidades religiosas que se han considerado en esta ocasión son conflictos que no se dirimieron ante un tribunal eclesiástico sino que se solventaron mediante una convenientia de forma similar a otros pleitos horizontales entre señores laicos. Exceptuando, por tanto, los pleitos que se dirimieron ante altas instancias eclesiales, el resto conforma un total de 48 diplomas.

\section{Pleitos GeStionados BAJO ARBitRAJE REAL}

\subsection{Entre señores laicos y eclesiásticos}

En el conjunto de conflictos horizontales analizados, un $43 \%$ son pleitos entablados entre un señor particular y una entidad eclesial bajo arbitraje real. El ejemplo más temprano del corpus es un documento de 1031 relativo a las querellas surgidas con motivo de la ocupación por parte de ciertos seniores de la decanía de Zamarce, dependiente del obispado de Pamplona (CDCPamplona, 10, a. 1031). El diploma, que ordena escribir Sancho el Mayor, menciona explícitamente el objeto del litigio entre el obispo y el rey tras la intitulación y la mención del tipo documental: la decanía, que había sido siempre episcopal, estaba ahora en manos de señores vasallos del rey. Ante la querella presentada por el obispo, el rey convoca un concilium en Pamplona con todos los señores y ancianos del territorio junto con el obispo (omnes seniores et homines senes qui erant in terra) y les insta a jurar la verdad. El elemento clave para emitir la sentencia es el testimonio unánime de los congregados: testificauerunt omnes ex uno ore quod episcopale erat semper. La escucha de la verdad, garantizada por el juramento previo, permite al rey zanjar el conflicto y redactar un documento que testimonia la resolución con la correspondiente cláusula conminatoria. Sin embargo, posteriormente, en el reinado de García de Nájera algunos "señores perversos" reabren el conflicto (seniores maligni eleuauerunt pleitum) y el obispo junto con el rey convocan de nuevo a los "ancianos de la tierra" para que ratifiquen la verdad anteriormente reconocida. Tras la segunda asamblea judicial el documento se rescribe de nuevo (de capud est cartula ista renouata et similiter confirmata) y una serie de seniores y milites firman como testigos. Como puede apreciarse, el diploma yuxtapone hechos ocurridos en dos momentos distintos en relación a un conflicto no resuelto definitivamente. La primera parte del relato, narrado en primera persona por el rey, subraya la actitud prudente, ecuánime y legalista de este. Ante la querella presentada por el obispo, el rey toma la decisión de convocar una asamblea de acuerdo con el obispo (prouide iussi ego... simul cum illo episcopo) y reúne en ella a todos los señores y ancianos del territorio, quienes, tras prestar 
juramento, reconocen unánimemente la titularidad episcopal de la decanía. La insistente repetición del adjetivo omnes referido a los numerosos miembros de la asamblea y a la unanimidad de la sentencia adoptada, pretende garantizar la verdad incuestionable defendida por el obispo así como la legalidad de la misma. Además, el rey, al acatarla, se muestra como un mandatario defensor de la justicia y la legalidad. Sin embargo, la segunda parte del diploma correspondiente al reinado de García de Nájera y narrada por el mismo obispo Sancho, muestra que el procedimiento judicial anterior no fue efectivo ya que algunos seniores reabrieron el pleito y tras un nuevo proceso el documento se tuvo que rescribir. Una diferencia importante con respecto al primer escrito es que el diploma reelaborado contiene la firma de una larga serie de testigos, señores, obispos y milites que dejan constancia del acuerdo. El escriba añade un comentario final en el que se disculpa por no incluir más nombres en la lista testifical: no es por desidia sino por falta de espacio ${ }^{26}$. En un momento en que las rivalidades señoriales en lucha por el poder podían minar la autoridad real, el diploma subraya la alianza del rey con el obispo y subraya la actuación legalista de ambos así como los apoyos con los que cuentan. La adición de la importante lista de testigos que cierra el documento ${ }^{27}$ parece corroborar el apoyo señorial con que cuenta el binomio obispo-rey frente al grupo de señores enfrentados a causa de la decanía. Hay que tener en cuenta, además, que el sistema de los obispos-abades se habría formalizado con Sancho el Mayor a partir de 1024 a través de un concilio celebrado supuestamente en 1023 con motivo de la restauración de la sede pamplonesa ${ }^{28}$. En dicho concilio se decretó, entre otras decisiones, que el obispo de Pamplona fuera elegido entre los monjes de Leire y que este jurase fidelidad al monarca ${ }^{29}$. Esta relación de lealtad se refleja en la actuación unitaria del rey y del obispoabad y la defensa conjunta de la legalidad jurídica en un asunto de usurpación de

\footnotetext{
26 "Set tu, lector, precor ut non reputes mihi scriptori et quod non scripserim eos bene per ordinem, quia, ut tu uides, necessitas paginam maiorem non habendi fecit mihi sic et non segnities manuum mearum nec sensus nesciendi animi mei".

27 "Et isti omnes cum militibus suis et alii plurimi seniores de Pampilona et de Alaua et de Castella et de Aragone quorum numerum longum est scribere".

${ }^{28}$ La redacción actual del diploma se habría llevado a cabo, según Fortún, hacia 1120 en un momento de enfrentamiento entre Leire y el obispado pamplonés a causa de un supuesto privilegio de exención papal cuya concesión el cenobio pretendía probar (2005, p. 213). Este documento manipulado presentaría, por tanto, una imagen armoniosa entre el rey y el obispoabad en un momento en que la protección real hacia el cenobio no era tan patente. Por otro lado, la creación de la figura del obispo-abad por parte de Sancho el Mayor estuvo influenciada por la actuación en el mismo sentido de Oliba, abad de Ripoll y obispo de Vich. El unir en la misma persona ambos cargos tenía como finalidad consolidar la sede episcopal, debilitada por las luchas contra los musulmanes, uniéndola al monasterio más importante del entorno (Fortún 1993, pp. 96-97).

29 "Item promittant et uoueant regi, cuius donatione hunc acceperint honorem, fidem integram et sine fraude servare et suo metropolitano obtemperare atque oboedire et sicut discipuli magistro suo servire" (CDCPamplona, 8).
} 
tierras en el que se vislumbra, más allá del objeto concreto de litigio, el pulso de fuerzas entre los miembros de la élite señorial.

El binomio rey-obispo vuelve a aparecer en DMLeire, 52 (a. 1050): el señor Enneco había donado una serie de tierras y viñas al monasterio del Santo Ángel de Egurzanu y otras a sus nietos. Tras su muerte, el monasterio recibió lo que por derecho le correspondía (habuit suo directo) pero, posteriormente, el obispo-abad de Leire Sancho "el Mayor" solicitó dicho monasterio de Egurzanu al rey García Sánchez IV y este se lo concedió ${ }^{30}$. Sin embargo, cuando el abad llegó al monasterio se apropió también de las tierras legadas por Enneco a sus nietos. Estos esperan un tiempo y aprovechan la nueva coyuntura que se crea tras la muerte del rey García (a. 1054) y la del mencionado obispo Sancho para presentar una querella ante los sucesores de ambos en Leire. El rey Sancho Garcés IV y el obispo Juan, sucesores de los anteriores, ordenan celebrar un juicio justo (iudicio directo). No se ofrecen datos concretos de la asamblea judicial, solo la decisión tomada por los maiores de Leiorensis quienes, tras exponer su testimonio ante ambas autoridades, emiten su veredicto: devolver a los nietos de Enneco lo que reclamaban. El aspecto más llamativo del relato es la imagen que el escriba ofrece de la actuación del obispo-abad Sancho: la presenta como un abuso de poder que se impone sobre la voluntad del donador y se repara solo cuando cambia la persona que ejerce el cargo. Ante la probable inexistencia de testimonios escritos que pudieran avalar el derecho de propiedad de los nietos de Enneco, la rectificación y el abandono de las tierras injustamente ocupadas depende de la actitud del nuevo obispo y del respeto que muestra hacia la memoria colectiva representada por los ancianos. Como señala Andrade, pese a la importancia creciente de los instrumentos escritos, algunas cuestiones como las relativas a los derechos de propiedad, solían solventarse recurriendo más a la memoria viva ... que a la documentación escrita ${ }^{31}$. En este sentido, cabe señalar que, si bien el término habitual para hacer referencia a los ancianos es senes o maiores, en algún caso el sustantivo senior parece presentar el significado etimológico junto con el habitual de señor, tenente o representante real ${ }^{32}$. Así lo sugiere el contexto, a nuestro parecer, en el diploma DMLeire, 116 (a. 1085): Sancho Ramírez

${ }^{30}$ Sancho el Mayor, obispo de Pamplona vivió en tiempos del rey Sancho III el Mayor y de su hijo García el de Nájera y estuvo al frente del episcopado entre 1024 y 1052. Algunos documentos, como este que nos ocupa, le adjudican el sobrenombre de Maior, en contraste con el de Sancho el menor que le atribuyen algunos historiadores. Sobre los documentos que testimonian su gestión y los equívocos entre este obispo y su homónimo de Nájera véase Goñi Gaztambide 1979, pp. 159-194; Fortún 2005, p. 217.

${ }^{31}$ Andrade 2012, p. 12.

32 Sobre el significado del término senior y su evolución en la documentación navarra, véase Larrea 1998, pp. 226-230; Guijarro 1988, pp. 98-99. 
concede a Leire el monasterio de Igal con todas sus pertenencias pero un señor, Jimeno Garcés de Güesa, presenta querellas repetidamente (contradicebat et proclamabat et querelabat) afirmando que dicho monasterio le pertenece. El rey acude al monasterio con su comitiva de nobles y caballeros para solventar la causa (cum principibus, potestatibus ac militibus suis plurimis et senioribus terre et ibi multum confabulatum et perquisitum est de ista causa). Es posible que la expresión seniores terre en este contexto designe a los ancianos del lugar ${ }^{33}$ ya que el término se cita después de la alusión a los nobles y caballeros de la comitiva real y parece constituir una expresión hecha que en otros diplomas se forma con el sustantivo senes en lugar de seniores, como ocurre en CDPamplona, 10 (senes terrae). Por otro lado, el procedimiento para solucionar el conflicto es el habitual, a saber, celebrar un juicio o asamblea pública en el monasterio objeto de litigio, solicitar el arbitraje del rey y su comitiva, escuchar la opinión de los principales y los ancianos del lugar y cumplir la sentencia dictada. Cabe destacar en referencia al debate judicial la utilización de la expresión multum confabulatum et perquisitum est de ista causa. El verbo confabulari evoca la noción de hablar en una asamblea, debatir. Además, el adverbio subraya la intensidad del debate oral tras el cual el rey y todos los convocados toman una decisión unánime $^{34}$. La investigación de la verdad, ante la supuesta ausencia de documentos escritos, vuelve a sustentarse en un debate liderado por los nobles y los "sabios" del lugar, es decir, los guardianes de la memoria colectiva. Por otro lado, cabe destacar en este caso el epílogo del documento ya que parece transmitir una determinada imago regis: con actitud compasiva el rey perdona al responsable de la querella los mil sueldos que debía abonar por la misma y le devuelve su favor. Sin embargo, en este y otros documentos, bajo la imagen de piedad y clemencia cristiana que se le atribuyen al monarca, subyace probablemente la voluntad de evitar represalias futuras por parte de un noble despechado. Dicha imagen adquiere además especial relieve en un documento en el que se ha subrayado con una expresión elocuente la persistencia del querellante al presentar su demanda así como la intensidad del debate. Lo que, en realidad, parece sugerir el diploma

${ }^{33}$ Davies (2007, pp. 30-31) ha planteado la posibilidad de que los seniores de la documentación altomedieval puedan referirse en ocasiones, no a los nobles o a los principales del lugar sino a los expertos por edad, es decir, a los ancianos: aduce como ejemplo documentos bretones del siglo IX en los que el término se aplica a gentes que, sin duda, son campesinos (citado por Andrade 2012, p. 16, n. 19).

${ }^{34}$ Es también una expresión técnica la que en este diploma y otros expresa el acatamiento de la sentencia por parte de los miembros de la asamblea: "omnes laudaverunt et confirmauerunt unanimiter" (todos concedieron y confirmaron por unanimidad): $c f$. Du Cange 1883-1887, s. v. laudare $^{3}$ " "laus, donatio seu potius concessio"; laudare ${ }^{2}$ auctorizare, "affirmare seu potius confirmare". En la misma línea, el sustantivo "laudatio" puede significar tanto "consenso" como "pacto o asentimiento" y la expresión "definivit ac dimisit", "cede y deja": cf. Du Cange 1883-1887, s. v. definitio "rei alicuius cesio, abdicatio". 
es que la solución del conflicto se ha logrado mediante un pacto tras una negociación ardua: el acuerdo aportaría beneficios para ambas partes y serviría para mantener el vínculo vasallático del rey con el noble querellante en un período en el que las rivalidades señoriales podían amenazar el poder real ${ }^{35}$. Por otro lado, a pesar de la utilización de vocablos como iudicium o iudex y la constitución de asambleas o concilia, no se alude a la utilización de código legal alguno que sirva de referente para la toma de decisiones. Más bien, son la memoria colectiva, los usus terrae así como la voluntad de los poderosos y los vínculos establecidos entre ellos los que condicionan la resolución del conflicto ${ }^{36}$.

La transmisión de legados testamentarios, uno de los motivos más habituales de pleitos, provocaba a menudo conflictos jurisdiccionales, sobre todo, tras la intensificación del proceso de señorialización durante la segunda mitad del XI. Un ejemplo representativo es DMLeire, 62 (a. 1060), diploma que ordena Sancho Garcés IV a petición de San Juan de la Peña para confirmar el derecho de propiedad de este monasterio sobre la villa de Zarapuz. Sancho el Mayor había donado dicha villa a un eunuco suyo llamado García. Este la legó a su vez al monasterio pinatense pero posteriormente un monje llamado Amusco construyó en ella un monasteriolo y lo donó a Leire ${ }^{37}$. El hecho fue examinado a la luz de la normativa canónica (per canonum censuras deuictum) ante el rey y sus señores y la jurisdicción de la villa le fue reconocida a San Juan de la Peña. En esta ocasión existía un diploma que acreditaba la donación del Mayor (rex Santius dedit... obsequium per cartam) pero a pesar de ello, el de Peñalén tuvo que recurrir al testimonio oral (sicut a plurimis uerum esse cognoui) para confirmar que Sancho el Mayor había entregado la villa íntegramente a García. Así, el proceso judicial ratifica la pertenencia de Amusco y de su monasteriolo a la jurisdicción de la villa y refleja las ilegalidades en que se podía incurrir si no se respetaba la sujeción de personas y bienes a villas y señoríos. Las cláusulas conminatorias subrayan con insistencia la imposibilidad de dividir la villa, concedida íntegramente al cenobio pinatense, por medio de una enumeración que precisa la casuística

${ }^{35}$ Como señala Alfonso, la cultura legal de esta época, sustentada en una densa red de intereses, alianzas y dependencias señoriales, explica el carácter negociado de las resoluciones adoptadas con las que se solventan, al menos temporalmente, los litigios (1997, p. 953. Cf. Geary 1986, p. 1108).

${ }^{36}$ Geary 1986, pp. 1117-1118. Larrea (1998, p. 459) señala que la expresión "lex terrae" empieza a hacerse frecuente a fines del s. XI y se utiliza para hacer referencia a los dos aspectos principales del proceso judicial: la prestación del juramento como elemento probatorio y el establecimiento de fiadores como medio de garantizar los acuerdos.

37 Siguiendo la práctica de la "traditio corporis et animae", el monje se había encomendado junto con su monasterio a San Salvador de Leire (Larrea 1998, p. 405). 
más habitual que podía dar lugar a una hipotética división ${ }^{38}$. Por otro lado, el monarca añade que quien conceda algún tipo de ayuda o prestación a dicho monasterio, recibirá su favor además de recompensas espirituales. Es evidente en esta cláusula y en todo el documento la voluntad regia de respetar la jurisdicción de la entidad monástica e incluso promover su crecimiento para lograr beneficios espirituales. Junto a esta actitud, se subraya el valor de la autoridad real para legitimar y dar firmeza a la resolución adoptada (ut regia habeatur potestas talem concedo firmitatem et stabilitatem). El recurso de los monasterios al arbitraje real se apoyaba, tal como se advierte en ocasiones de forma explícita, en el patronazgo espiritual que el monarca mantenía con el monasterio, relación que les aportaba ventajas mutuas. Así, por ejemplo, el diploma DMLeire, 63 (a. 1061), aunque no contiene propiamente el relato de ningún conflicto, parece aludir a una vinculación de ese tipo entre Sancho Garcés IV y el monasterio legerense ${ }^{39}$.

En dicho contexto de conflictividad y lucha de intereses señoriales, la existencia de testimonios documentales no constituía siempre una garantía de veracidad. En DMLeire, 127 (a. 1088) se constata que los escritos aducidos como prueba podían ser objeto de manipulación consciente por parte de señores que pretendían ampliar su patrimonio. En el diploma citado se relata el acuerdo que firmó el monasterio con Lope Arceiz de Ayesa, el cual había comprado una viña en el término real de Erauso en tiempos del rey Sancho Garcés IV; posteriormente, tras la muerte del rey, manipuló el diploma, falsificó los términos de la compra (per falsitatem posuit in ipsa carta duas vineas post mortem eius) y presentó el documento ante Sancho Ramírez con la querella correspondiente para someterla a su arbitraje. El rey, ayudado por sus jueces, reconoce su falsedad y ordena que el tal Lope Arceiz pierda las dos viñas y que estas sean entregadas a Leire. A pesar de la sentencia, el acusado acude ante el abad para solicitar clemencia y no perder totalmente las viñas. El cenobio le cede una de las dos en usufructo a condición de que entregue al monasterio el diezmo correspondiente. Además, tras la muerte del citado Lope o su esposa, el/la cónyuge debía entregar

38 "Neque rex neque senior neque episcopus neque abbas neque cuiuslibet potestatis homo neque per donationem neque per commendationem neque per profilationem neque per quamcumque occasionem excepta uoluntate sancti Iohannis".

${ }^{39}$ El monarca otorga una donación material al monasterio y a cambio obtiene apoyo espiritual para hacer frente a asechanzas familiares y señoriales. La parte final del documento vuelve a aludir a la existencia de conflictos del rey con los nobles: "dono uel mito ad sanctum Saluatorem... eo quod fuerunt mikhi rogatores ad Deum in tribulatione que aduenit mihi cum senioribus patrie mee, ut habeant eum et possideant perpetim ingenuum... et ud sint mei memores post transmigrationem huius seculi (...) Si quis enim ex germanis meis uel quislibet ex senioribus terre uoluerint hanc donationem meam disrumpere uel eum monasterium traere de Sancto Saluatore, illum ipsum sanctum Saluatorem uel eas sanctasque habeant contrarios uel inimicos in hoc seculo et in futuro, amen". 
una mitad al monasterio y a la muerte de ambos, la viña entera ${ }^{40}$. En realidad, la cesión de la propiedad en usufructo permitía al monasterio ofrecer una salida aparentemente "piadosa" sin perder los derechos de propiedad sobre aquella, asegurándose al mismo tiempo el favor y la dependencia del señor en cuestión ${ }^{41}$. Convenientiae que se presentan como acuerdos piadosos por parte del monasterio pero que pretenden salvaguardar los intereses señoriales se relatan también en DMLeire, 196 y 205. En el primero de ellos, los hermanos Jimeno, Sanz y García Fortuñones de Iso tras haberse apropiado de los términos del monasterio de Santa María de Uarra, propiedad de Leire, son convocados a juicio ante el rey Sancho Ramírez y su hijo Pedro y mediante juramento ante el altar de Leire reconocen la falsedad de su reclamación. A continuación, el abad recurre a los ueteres homines para determinar las lindes del término disputado. Aunque el juramento permite, en palabras del escriba, imponer la verdad y poner fin al litigio, el monasterio "concede" a los homines de Iso el usufructo de las tierras disputadas a cambio de la entrega de ciertas cargas y prestaciones. Además, se recuerda en el diploma la competencia jurídica del cenobio para impartir justicia en su jurisdicción en caso de incumplimiento del acuerdo (et non incidant arbores nostros; quod si fecerint, compleant legem nobis). En definitiva, la sentencia se presenta como un pacto ventajoso para los querellantes, pacto que se ofrece per voluntatem et per licenciam monachorum si bien son los intereses señoriales de la entidad monástica los que bajo una apariencia de concesión piadosa condicionan la cesión del uso. Una resolución similar se adopta en DMLeire, 205.

Las escrituras existentes, además de manipularse, podían destruirse. Los acuerdos pactados entre señores y abades constituían en muchos casos convenientiae frágiles que no ofrecían soluciones definitivas. Así se observa en DMLeire, 157, donde la mención misma del tipo documental refleja la complejidad del proceso: hec est carta definicionis, euacuacionis siue confirmationis. A continuación, se resumen los antecedentes del conflicto: doña Sancha de Fortuñones había donado a Leire mediante el correspondiente diploma el monasterio de Santa María de Elizaberria, varias villas y un palacio. Sin embargo, tras su muerte sus nietos quisieron destruir tal diploma y

\footnotetext{
40 "Quapropter fecit ei istam misericordiam: ut illam uineam adermatam que est iuxta terminum de uilla Garoiz... non requirerent in eternum nec ipse nec ipsa neque aliquis, et alteram uineam tenuisset in uita sua que est iuxta proprias uineas Sancti Saluatoris et uxor sua predicta, et dedissent fideliter decimum ad Sanctum Saluatorem et qui prior obisset dedisset medietatem Sancto Saluatori pro anima sua; post mortem autem amborum tota et integra supradicta uinea remanssiset sancto Saluatori in Leiorense cenobio pro remedio animarum suarum et parentum suorum".

${ }^{41}$ Esta solución que se observará en otros conflictos corresponde a la práctica del llamado "prestimonium" en el reino de León. Dicha modalidad "suponía la concesión a los laicos del disfrute de ciertos bienes de forma vitalicia, que debían revertir a los establecimientos religiosos a la muerte del beneficiario" (Pérez 2015).
} 
promover un pleito. Después de muchas querellas, el rey Sancho Ramírez y su hijo Pedro consiguen restaurar la concordia entre las partes mediante un pacto que implica la repartición de los bienes objeto de litigio: las villas de Ariz y Eneriz y el palacio para los nietos y el monasterio con sus términos para Leire. Como se puede advertir, la existencia de un supuesto diploma de donación no garantizaba que hubiera de ser respetado. La mediación real es la que los conduce a la negociación de un acuerdo que consigue zanjar el enfrentamiento, al menos, temporalmente.

Presenta especial interés el conflicto relatado en DMIrache, 82 ya que en el mismo confluyen todos los factores enumerados hasta aquí (escrito de donación, querella para invalidarlo, alianzas señoriales, negociación de reparto territorial): la señora Urraca entrega toda su heredad a Irache a cambio de recibir sustento mientras viva de forma que suscribe públicamente un documento que testimonia la donación y lo ofrece ante el altar. Después de más de un año de sustento a cargo del monasterio, la tal Urraca inicia una relación con el caballero Aznar Oriol y se desdice del compromiso firmado: ambos solicitan al abad la devolución de la heredad donada. Este considera absurdum et nefarium restituirles la propiedad sin un juicio legal (iudicium patrie). En esta tesitura, la pareja amenaza con recurrir a sus amigos (amicorum suorum auxilia) y finalmente tanto estos como los monjes aconsejan al abad que ceda la heredad alegando que dicha solución es preferible a soportar continuamente procesos judiciales (iudicium et legem ipsius patrie continuo subire). Es interesante en este punto la mención a la ley por parte del escriba monástico ya que es el único caso en el corpus analizado en el que no se menciona genéricamente mediante las fórmulas legem complere o lex terrae sino que el escriba parece aludir a una norma legal sobre las condiciones en que debía realizarse una donación:

Lex enim erat ut si domna illa ausa fuisset iurare hereditatem illam se monasterio non dedisse et cartam suam voluntate non esse scriptam, nec suo iussu nec firmatam sua manu, cum sua radice ad propria reverteretur.

Aunque en Navarra y Aragón la tradición jurídica visigoda no se manifiesta tan explícitamente como en Cataluña o Castilla, los procedimientos jurídicos y el énfasis en los pactos parecen tener su raíz en el pasado romano-visigodo ${ }^{42}$. En este sentido, parece probable que el escriba mediante la expresión Lex erat haga referencia a las cláusulas de libre voluntad y espontaneidad propias de los actos de donación, cláusulas que, en última instancia, remiten a los títulos V, 2, 1 y 6 de la Lex Visigothorum donde se

${ }^{42}$ Salrach 1997, p. 1024; Collings 1986, p. 104; Larrea 1998, pp. 457-467. 
prescriben las condiciones que garantizan la validez de una donación ${ }^{43}$. En cualquier caso, la amenaza surte efecto y el abad tras aceptar la devolución de la heredad donada nombra dos fiadores para garantizar que dicha heredad fuera de nuevo propiedad del monasterio tras la muerte de la pareja. Sin embargo, el conflicto continúa ya que García Lópiz de Chávarri, uno de los fiadores designados, alega que la heredad en cuestión la había tenido él anteriormente por designación del monasterio y si ahora se la arrebataban no era por prescripción legal sino por el apoyo prestado a la pareja por sus poderosos amigos (nec iudicio legum set suffragio et potentia illius amicorum). Finalmente, la pareja propone al abad un nuevo pacto y este, aconsejado por los boni homines, acepta dividir los bienes entre las partes enfrentadas tras lo cual recibe la promesa de fidelidad de García Lópiz ${ }^{44}$, que se declara fidelissimus Sancte Marie amicus. El episodio muestra claramente el escaso valor probatorio de los documentos e incluso del juramento: las soluciones pragmáticas, es decir, pactadas, se consideran más efectivas si bien en este como en otros conflictos, se trataba de convenientiae frágiles que no ofrecían soluciones definitivas y que dependían de las fidelidades señoriales establecidas y del poder de los señores implicados en la negociación.

Aunque los pactos y cesiones constituyen el medio más efectivo para solventar conflictos, en algún caso el acuerdo se completa con una donación generosa al monasterio por parte del señor querellante sin ninguna contrapartida aparente. En DMLeire, 158 el objeto de litigio son unas arenzadas de viñas unos señores dependientes de Leire (seniores Sancti Salvatoris) habían hecho plantar en un terreno colindante con las villas de Aldunate y Nardués. Tras esta ocupación, el señor Lope López de Liédena presenta una querella y pide una compensación al monasterio (contradicebam et interpellabam et pignorabam iugiter). Finalmente, tuvo lugar un juicio en el que se decidió zanjar el conflicto mediante un juramento de ambas partes ante el altar de Lei$\mathrm{re}^{45}$. Lope López precisa que, además del juramento, dos seniores apoyados por los restantes miembros de la asamblea aconsejaron al abad Raimundo la devolución de las viñas (consiliantibus senioribus... predictus abbas redidit

${ }^{43}$ Lex Visigothorum, V, II, 1: "Ne valeat nolenter facta donatio"; Lex Visigothorum, V, II, 6: "Hoc tantum observandum est, ut si donator dixerit nec dedisse nec direxisse scripturam sed sublatam sibi fuisse, tum ille cui res donate sunt, per testem convincat, ab ipso donatore eandem aut traditam sibi aut directam vel ex eius volumtate in potestate sua redactam et dum probaberit, stabilis habeatur. Quod si probare neclexerit, invalida remanebit".

${ }^{44}$ Como señala Larrea (1998, p. 466), la autoridad y poder de García Lópiz, que en DMIrrache, 105 aparece como tenente de Mendavia, así como los apoyos con que contaba influyen decisivamente en la decisión del abad.

45 "Ego autem senior Lope Lopeiz iam dictus contradicebam et interpellabam et pignorabam iugiter illos de Altunat donec iudicatum est inter nos fecissemus sacramentum super altare Sancti Salvatoris". 
et definivit illas uineas), decisión que el abad acató. Sin embargo, la decisión final de Lope fue donar dichas viñas a Leire para que el cenobio las poseyera en propiedad. En este caso, el reconocimiento y acatamiento de la sentencia por parte del abad parece haber promovido en respuesta la donación de los bienes disputados como ofrenda para el monasterio. Cabe señalar también en este documento un uso del plural seniores con el significado etimológico, junto con el habitual de "señor, noble" en el resto de menciones: la decisión tomada por la asamblea la habrían propuesto dos de los miembros de más edad $^{46}$. Por otro lado, la donación sugiere que el señor citado pretendía seguir manteniendo una relación de fidelidad con el monasterio al que en años posteriores siguió dotando con generosidad ${ }^{47}$. Lo mismo cabe decir de DMLeire, 273 donde se relatan por boca de los hermanos Sancho, Lope y Sancha López de Domeño las querellas que mantuvieron con el monasterio a causa de las heredades legadas por su padre a Leire. Tras la celebración de un juicio ante el rey y el establecimiento de una convenientia cuyos detalles no se explicitan, los hermanos declaran que desean ir más allá de la decisión judicial y realizar una serie de donaciones a Leire renunciando a parte de los bienes disputados ${ }^{48}$.

En esta serie de conflictos "horizontales" entre señores laicos y entidades religiosas, la solución del enfrentamiento implica la realización de un juramento si bien en pocos diplomas se precisan detalles acerca del mismo. En DMLeire, 171 (a. 1099), se relata el conflicto que enfrentó al cenobio legerense con los familiares de Jimeno Garcés. Este había legado en su testamento a Leire la villa de Altunat, que le había sido otorgada por Sancho de Peñalén en $1068^{49}$, así como el palacio que poseía en Aibar con sus tierras.

${ }^{46}$ En el contexto mencionado el término "seniores" designa, a nuestro parecer, a los más ancianos de entre los convocados para desempeñar el papel de jueces ya que el adjetivo se refiere en aposición a dos de los miembros de la asamblea reunida para enjuiciar el hecho y seguidamente enumera a ambos haciendo preceder el nombre del honorífico senior: "postea uero remanentibus sacramentis, consiliantibus senioribus, senior Garsia Eximinone de Lumberri et senior Fortunio Arceiz de Arteda cum cetris hominibus". Si no tuviera el sentido etimológico citado, el ablativo senioribus sobraría ya que sería suficiente nombrar a ambos "seniores" tras el participio "consiliantibus". Wendy Davies, teniendo en cuenta la importancia del testimonio de los ancianos en la resolución de ciertos conflictos, cree posible que el término "seniores" aluda en documentos del siglo X del norte peninsular a los más expertos por su edad y no necesariamente a los más ricos (2007, p. 30).

47 Tales donaciones se recogen en DMLeire, 257, 274. Se puede constatar, además, que el monasterio acogió como monje a un hijo de Lope Lópiz, tal como lo prueba la mención del mismo como confirmante en DMLeire, 274 ("Fortunii Lopiz monachi filii eiusdem senioris").

${ }^{48}$ Es elocuente la expresión que el escriba monástico atribuye a los hermanos: "Tandem itaque nolentes nec ualentes secundum racionem iudicialem nos prescripti fratres agere, concedimus Sancto Saluatoris... bono animo et spontanea uoluntate": los encausados no quieren actuar ateniéndose estrictamente a la decisión judicial y acuerdan ir más allá y donar parte de los bienes disputados.

${ }^{49}$ Véase DMLeire, 83. 
Treinta años después, los hermanos Lope y Fortún Garceiz de Eslava y Ayesa reclaman dichas propiedades ante el rey Pedro. El diploma no ofrece detalles del juicio que tiene lugar, solo precisa que el rey junto con los nobles y jueces de Pamplona (cum principibus et iudicibus Pampilonie) ${ }^{50}$ estableció que el hijo del fallecido, Jimeno Garcés, acompañado de otro caballero, debía jurar y confirmar la donación que su padre había hecho al cenobio antes de morir. Dicho juramento, pronunciado junto con otro caballero en calidad de fiador secundum morem patrie, se realiza ante el altar, en presencia de los caballeros que reclamaban dichas propiedades ${ }^{51}$ pero no se especifica en qué consistía dicha "costumbre". En CDIrache, 27 (1055-1063) se alude en estilo indirecto a una parte del contenido de un juramento de este tipo: la petición de intercesión espiritual a cambio de la cesión de los bienes disputados ${ }^{52}$. En cualquier caso, el juramento tiene un valor probatorio mayor al de cualquier escrito ${ }^{53} \mathrm{y}$ los escribas lo subrayan en diversas ocasiones por medio de la fórmula quia non potuerunt iurare falsitatem, recognouerunt ueritatem.

Podía ser también motivo de confrontación el deseo de acceder a las ventajas que comportaba ser infanzón o miembro de la baja nobleza ya que dicho status requería ser probado, tal como se constata en DMLeire, 194 (a. 1102). El escriba comienza manifestando que la villa de Aldea, donada a Leire por doña Mancia, estaba habitada por mezquinos y no había en ella sino un infanzón, Sancho Garceiz. Eneco Garcés y su hermana, hijos del susodicho, tratan de reivindicar su condición de infanzones y el abad, junto con el señor García Fortuñón de Capanas presenta su querella ante el rey por dicha causa. Este ordena a los hermanos cumplir la lex terre y al no poder hacerlo, queda reconocida su condición de mezquinos. Es interesante en este documento la alusión a un procedimiento para probar la pertenencia a la infanzonía si bien el diploma no ofrece detalles sobre el mismo ${ }^{54}$. Según

${ }^{50}$ El término "iudex", tanto en la expresión "cum principibus et iudicibus", como, en general, en los documentos previos, alude a los "boni homines" que asesoraban al rey; estos tenían la potestad de sugerir propuestas resolutivas y ratificar la sentencia emitida por aquel o por quien presidía la asamblea sin que ello implicara un ejercicio profesional de la función judicial. Salrach recuerda que el significado amplio del término "iudex" (todo el que ha recibido la potestad de juzgar) se encuentra ya en la Lex Visigothorum, II, 1, 27 (Salrach 1997, p. 1014, n. 18).

${ }^{51}$ El juramento prestado en un lugar sagrado comportaba una garantía de veracidad que era refrendada por el carácter público del acto ante otros nobles, caballeros y clérigos.

${ }^{52}$ En el diploma se alude al levantamiento de cinco señores contra Irache para arrebatarle el monasterio de Oiuni. Sin embargo, tras haber hablado en presencia del obispo Nuño y el abad Veremundo, los citados señores entregan el bien disputado mediante un juramento: "tradiderunt illud uniuersi sancte marie de Iraxe quasi cum manibus suis dicentibus illis ut intercederet sancta Dei Genitrix pro illis ad Dominum".

${ }^{53}$ Larrea 1998, p. 458.

${ }^{54}$ Frente a la dependencia señorial que comportaba la condición de villano o mezquino, "los infanzones eran un grupo conformado mayoritariamente por campesinos que disfrutaban 
indica Martín Duque ${ }^{55}$, la prueba testifical de infanzonía más temprana en Navarra está documentada a comienzos del s. XII aunque reflejaría costumbres mucho más antiguas ${ }^{56}$. La lex terrae consistiría en la formalización de un juramento ritual realizado por dos o tres infanzones en favor del individuo que pretendía acreditar su condición ${ }^{57} \mathrm{o}$ en la presentación de una prueba testifical. Resulta llamativo también el hecho de que los hermanos que pretendían reivindicar su condición de infanzones no pudieran heredar dicha condición de su padre, que sí lo era: ambos hermanos acaban reconociendo su condición de mezquinos y comprometiéndose a pagar el censo al cenobio $^{58}$. En cualquier caso, este diploma testimonia la tentativa por parte de algunos campesinos de reivindicar una condición social que otorgaba ventajas tributarias y sociales en una época en que no había legislación escrita al respecto ${ }^{59}$. Sin llegar a aducir la pertenencia a un status de infanzonía, en un documento mucho más temprano del Becerro Galicano, una campesina, doña Mayor de Terrero, se rebela ante el obispo Sancho de Nájera negándose a realizar prestaciones en trabajo para el monasterio por considerarse de condición superior a sus convecinos. Aunque parece, como lo demostró

de una condición legal privilegiada. (...) Desde un punto de vista jurídico, se integraban en la nobleza y disfrutaban de un estatuto privilegiado que afectaba a la fiscalidad, la justicia y el honor" (Tomás Faci 2015, pp. 320-321). En el caso navarro la regulación de las obligaciones y derechos de la condición de infanzonía se conoce por escrito gracias al Fuero General de Navarra (Díaz de Durana 2016, p. 356).

${ }_{55}$ Martín Duque 2002, p. 674.

56 "Ego Aldefonsus... rex Aragonum... facio hanc cartam franquitatis tibi Enneco Exemennes de lassa et ad totam tuam generationem... et uolo quod nomines de totam meam terram sciant quod tres infançones uenerunt iurare pro te et pro tua infançonia ad meam cappella in Ardenes" (Lema Pueyo 1990, n. ${ }^{\circ} 231$, a. 1130).

${ }^{57}$ Laliena 2012, p. 117.

${ }^{58}$ La lex terrae que menciona el texto alude, sin duda, a los procedimientos para probar la condición de infanzonía. Por otro lado, de los hermanos, que no pudieron demostrar dicha condición, se dice que los había tenido de Auria Galindiz de la que no se ofrecen datos (no se concreta si era "uxor" del citado Sancho Garcés o si los hijos eran ilegítimos). Sea como fuere, si tenemos en cuenta la normativa recogida en el Fuero General de Navarra y los Fueros Generales de Aragón ya en el s. XIII, la infanzonía se podía heredar por vía paterna en ambos casos. En cuanto a los matrimonios mixtos, es decir, entre infanzones con campesinas, los hijos heredaban la infanzonía del padre pero no podían eludir la tributación correspondiente a las tierras heredadas de la madre. Quizá en este caso, la imposibilidad de cumplir con la lex terrae haga referencia a este aspecto fiscal, es decir, las tierras de Aldea correspondían a Auria Galíndiz, eran tierras cultivadas por mezquinos y por ellas debían seguir tributando al igual que los restantes mezquinos de Aldea: quizá lo que reconocen ante el abad es su obligación a seguir tributando de acuerdo con lo que la ley prescribía para los matrimonios mixtos pero el diploma no ofrece datos para concretar este aspecto (Díaz de Durana 2016, pp. 342-343).

59 "Entre la situación dibujada para el siglo XI y la de la Baja Edad Media mediaba un proceso largo y opaco que, por una parte, llevó a que el estatuto de los infanzones se codificase a todos los efectos, generalmente bajo el influjo del Derecho Romano, una tendencia que se inicia a finales del siglo XII y culmina con grandes compilaciones como el Fuero General de Navarra o los Fueros de Aragón de 1247” (Tomás Faci 2017, p. 52). 
Loring, que la alegación de doña Mayor vendría explicada por el hecho de que la población campesina de Terrero no sería homogénea y habría campesinos con ingenuidad que no tenían condición servil cuando la villa paso a depender de San Millán, episodios de este tipo prueban de forma elocuente los intentos de los campesinos vinculados a señores y monasterios de evitar la degradación de su condición social ${ }^{60}$.

Por último, hay que subrayar también que la imago regis que se desprende de la actuación real en un conflicto no siempre se corresponde con la de un mediador ecuánime. En DMIrache, 63 el abad Veremundo relata la presión a que lo sometió el rey Sancho Garcés IV para que renunciase a un dominio que el señor Lope Fortuñón de Calahorra había legado al monasterio. Aunque la donación testamentaria había tenido lugar muchos años antes, el rey envió mensajeros al abad en repetidas ocasiones (semel, bis et ter) para solicitarle el término perteneciente a la villa de Sotes a cambio de la de Legarda. Finalmente, el propio rey le insistió y amenazó de tal manera que el abad no pudo oponerse y aceptó el trato ${ }^{61}$. Tras el asesinato del rey y durante el reinado de Alfonso VI de León, un hijo del señor Lope Fortuñón, García Lópiz, reclamó al monasterio la mitad que correspondía a su madre en el dominio cedido por su padre y en el juicio celebrado en el monasterio resultó vencedor (habuit iudicium nobiscum... et uicti sumus iudicio). El abad, que aparece como ordenante del documento, justifica mediante el relato de los hechos la pérdida patrimonial que sobrevino al monasterio por la querella presentada por García Lópiz. Aparte del trueque de villas que constituye el núcleo de la disputa, es muy explícita en el diploma la imagen peyorativa que el relato del abad ofrece del rey Sancho Garcés IV ya que la mención de este le sirve de pretexto para recordar el tipo de muerte que sufrió: Sancius rex surrexit, qui interfectus est a fratre suo et a sorore uel a maioribus patrie sue. Aunque el diploma no relata un proceso judicial bajo arbitraje real, el autor del diploma se sirve del relato para presentar al rey, a través de los hechos que se le atribuyen, como un monarca autoritario y amenazador que obliga al abad a realizar una conmuta no deseada. El comentario gratuito del abad relativo al tipo de muerte que sufrió el rey sugiere el tópico de la muerte violenta que les espera a los tiranos. En general, en los casos analizados, la actuación real se reduce a la de un

${ }^{60} \mathrm{El}$ documento que relata el episodio de doña Mayor es BG 51 (año 1043) y fue estudiado por M.I. Lohring (1989, pp. 45-61). Como en el caso de la infanzonía, las palabras del obispo reflejan elocuentemente que la susodicha no pudo probar su condición no servil: "Ego autem, cum talem audirem errorem, cepi inqu[i]rere que nam esset, que tale quod facere auderet. (...) Cum autem voluit se excusare de servitute, non potuit, qu[i]a probavimus illam ex tribu servili fuisse genitam".

${ }_{61}$ "Ad ultimum uero, ipsemet ore suo deprecatus est etiam et minatus est, et nos, non ualentes resistere domno nostro, fecimus quod imperarat". 
mediador que en una asamblea de nobles y poderosos establece sentencias que favorecen los intereses señoriales, ya sean laicos o eclesiásticos.

\subsection{Enfrentamientos protagonizados por comunidades campesinas}

En cinco documentos del corpus el rey ejerce su mediación en conflictos entablados entre entidades religiosas y comunidades de campesinos. Se trata, por tanto, de enfrentamientos "verticales", es decir, socialmente desiguales. En este tipo de enfrentamientos se sigue la mecánica judicial tradicional pero el resultado final consiste en la imposición de los intereses señoriales más que en la negociación de una convenientia. El diploma más temprano que testimonia esta tesitura es DMLeire, 50 (a.1056). El conflicto surge cuando Sancho Garcés IV recompensa al señor Eneco Sánchez con el monasterio de Larraun y algunos de los términos adscritos al mismo son reivindicados por los hombres de Rasa. El rey acompañado de sus hombres (coram mea schola) y de los ancianos del lugar (homines vieillos) delimita las posesiones donadas a su vasallo a través de un recorrido que se lleva a cabo públicamente. Como pago por la firma del diploma de confirmación el rey recibe un mulo del citado Eneco Sanz. No se menciona nada con respecto a los campesinos de Rasa. Es evidente que la donación sirve para reforzar vínculos vasalláticos y que en tal contexto de desigualdad social no se establecen pactos ni cesiones en favor de los campesinos. En otros dos diplomas, uno emilianense y otro pinatense, de la primera mitad del s. XI se constata el mismo interés por favorecer los intereses monásticos frente a las reivindicaciones de comunidades que pretenden, según el escrito monástico, usurpar bienes o derechos del monasterio en cuestión ${ }^{62}$.

De un modo similar en CDCPamplona, 48 (a. 1094-1098), se refieren dos intentos de ocupación por parte de las comunidades campesinas

\footnotetext{
${ }^{62}$ En BG, 141 (a. 1076), se alude a un conflicto entre el cenobio y los "homines de Alesanco" a causa de unos molinos que estos habían ocupado con engaño ("tenuerunt falsatas") en el término de Terrero. En esta ocasión, Sancho Garcés IV emite el diploma de confirmación, tanto de dichos molinos como de una serie de villas en favor del monasterio y afirma haber celebrado un juicio para hacer justicia y otorgar a cada parte lo suyo ("vidimus bene et iudicamus per directum ut quisque unus haberet suum propium"). Se alega como motivo el hecho de que los vecinos de Alesanco carecían de documento alguno que acreditase la donación de los molinos ("cartam et viam recti dare non potuerunt"). Otro episodio similar cronológicamente anterior (CSJPeña, 174, a. 1035-1064) entre los vecinos de Botaya y el abad Blasco de San Juan de la Peña termina con la expulsión de los campesinos del espacio de monte ocupado ("Abuerunt contentione vicinos de Votaia cum abbate domno Blasco dicentes quod partem haberent in illo monte. Et per lege e iudicio de rege domno Ranimiro et de suos barones sakavit eos exinde... et iudicaverunt ut iurarent illos vivinos de Votaia"). En ambos episodios, ante la ausencia de escritos probatorios, el rey garantiza, ante todo, el mantenimiento de los privilegios señoriales monásticos.
} 
de Barbarín, Olejua y Etayo de los términos del castillo de San Esteban cuando este era regido por la condesa Sancha, hermana de Sancho Ramírez, y más tarde, por el conde Sancho. En ambas ocasiones, el cometido real se reduce a convocar una asamblea de nobles que junto con el alcalde realizan un recorrido, determinan públicamente las lindes del espacio ocupado por la comunidad campesina y ratifican la ilegalidad de la ocupación sin que haya pactos ni cesiones mínimamente ventajosas para los campesinos ${ }^{63}$.

Con todo, al igual que en los conflictos horizontales, la restauración de la concordia podía implicar algún tipo de negociación. En DMLeire, 162 (a. 1098) son los vecinos de Garde los que se enfrentan al cenobio legerense ante el rey Pedro por el régimen de la iglesia de la localidad dependiente del monasterio de San Martín del Roncal, propiedad de Leire. Los vecinos se rebelan y se niegan a recibir en su iglesia los sacerdotes del monasterio citado así como a entregar las prestaciones debidas. Tras las insistentes querellas presentadas por el abad Raimundo de Leire por la actitud de illis perfidis hominibus, el rey inicia las pesquisas e insta a los vecinos ut sine mendatio dicerent ueritatem de ista causa en un juicio que se celebra en Huesca ante los nobles, obispos y abades de la ciudad. Los de Garde temen no manifestar la verdad (timuerunt mendatium et falsitatem dicere metu regis et nobilium) y reconocen que anteriormente la iglesia de Garde recibía clérigos del monasterio del Roncal, que se regía por el rito toledano y que solían entregar los diezmos y oblaciones correspondientes a la iglesia de la localidad. El rey, por su parte, ordena que el régimen de la iglesia de la localidad tras la adopción del rito romano, continúe siendo el mismo que cuando estuvo vigente el rito toledano ${ }^{64}$. Los de Garde, tras oír la sentencia y comprobar la buena voluntad del rey, se presentan ante el señor de Rosta y del Roncal y firman un acuerdo con el abad de Leire en virtud del cual se comprometen a acoger a los clérigos de san Martín de Roncal y entregar la mitad de los diezmos y oblaciones correspondientes a la iglesia de Garde. El abad por su parte introduce mejoras para los de Garde en el fuero que regulaba el uso de los molinos del Roncal. Cabe destacar también en este caso la imagen real que quiere transmitir el escriba: la buena voluntad del rey, que es percibida por los vecinos, contribuye

${ }^{63}$ Sancho Ramírez ordena fijar los límites de las tierras pertenecientes a la jurisdicción episcopal que habían sido invadidas por los hombres de Barbarín, Olejua y Etayo. Además, el obispo Pedro relata en el mismo diploma un altercado similar entre los hombres del castro de San Esteban y los de Villamezquina por otro término, altercado que acaba con la victoria de los del castro de San Esteban, dependiente de la jurisdicción episcopal: "Congregauit comitem Sancium... cum multis aliis bonis hominibus (...). Et perquisierunt quod directum esset Sancti Stephani sicut perquisierunt perquisitores regis Santii".

64 "Rex autem ut audiuit et intellexit hec omnia, iudicando mandauit ut sicut fuerat factum in lege Toletana, ita et permansisset in lege Romana per omnia secula seculorum". 
a promover el acuerdo ante el iudex (omnes uicini... audito iuditio et precepto regis atque uoluntate bona ipsius uenerunt ante conspectum de senior Lope Lopeiz et fecerunt bonam concordiam). También la imagen del abad resulta favorecida en el relato judicial: tras la claudicación de los vecinos, los acoge fraternalmente y les restituye el fuero que poseían anteriormente con respecto al uso de los molinos del Roncal. En realidad, tal concesión implica el uso de los mismos por parte de los vecinos a cambio de la entrega de parte de la molienda y del compromiso de contribuir a su reparación cuando fuere necesario. La subjetividad con que se relatan los hechos no impide constatar la desigualdad social de los actores implicados, el carácter retórico de la piedad y fraternidad señoriales y las consecuencias reales del acuerdo con que se solventa el conflicto. Por otro lado, la fórmula que expresa la ratificación del mismo permite deducir que la condición social de los homines de Garde no era homogénea y que algunos gozaban de mayor preeminencia social. Estos últimos son los que consienten y firman el documento ${ }^{65}$. La presencia de nobles, monjes y clérigos y otros boni homines en el atrio del monasterio roncalense en una fecha litúrgica señalada, prueba el carácter ritualizado y solemne del acuerdo. En tal contexto celebrativo los vecinos ruegan al abad poder abonar solo la mitad del costo del juicio y ofrecer fiadores por la otra mitad. En conflictos de esta índole se perciben, como afirma Laliena, signos de rebelión por parte de comunidades de campesinos que mostraban mayor conciencia de los componentes degradantes de la servidumbre ${ }^{66}$, conflictos que se producen con más frecuencia desde finales del siglo XI y se dirimen mediante convenientias que garantizan la continuidad de un equilibrio social frágil.

Pocos años después protagonizan un enfrentamiento similar los vecinos de Navarzato (DMLeire, 191, a. 1102). El objeto de litigio es el régimen de la iglesia de San Sebastián sita en la villa citada y donada por los reyes de Pamplona al monasterio de San Martín del Roncal que, a su vez, había sido concedido al cenobio legerense por Sancho Ramírez en 1085 (DMLeire, 114). El procedimiento judicial y la convenientia aceptada por las partes implicadas sigue las mismas pautas que en el conflicto con los de Garde: el abad legerense presenta de forma reiterada su querella ante el rey y le muestra el diploma acreditativo de la donación. El rey, tras verificar la veracidad de la reclamación convoca un juicio juntamente con sus principes y establece que la citada iglesia de San Sebastián, tras la implantación del rito romano, debe permanecer bajo la jurisdicción del monasterio de San Martín en las mismas condiciones que cuando regía el rito

\footnotetext{
65 "Hec omnia confirmauerunt, iurauerunt et laudauerunt omnes meliores homines de Garde... ut fideliter teneant fraternitatem et amorem et confirmationem... Sancti Martini de Ronchali monasterio". Además, negocian con el abad la rebaja de la multa por el juicio y designan fiadores.

${ }^{66}$ Laliena 2012, p. 109.
} 
toledano: dichas condiciones implicaban aceptar los clérigos enviados por San Martín del Roncal y pagar a este monasterio la mitad de los diezmos y de todas las oblaciones recibidas excepto la correspondiente a un excusado de melioribus et potentioribus hominibus predicte ville. El acuerdo lo aceptan y ratifican todos los vecinos. Entre los testigos designados se citan, en primer lugar, los señores que fueron promotores o auctores istius concordie, y a continuación el alcalde, los clérigos y otros vecinos destacados de Nabarzato y Garde, la otra aldea que había mantenido un conflicto similar cuatro años antes ${ }^{67}$.

La ocupación de baldíos podía dar lugar también a conflictos entre los campesinos y los propietarios de los mismos, tal como se advierte en DMLeire, 169. El diploma se inicia con la mención de una donación que hizo Sancho el Mayor a Leire de varios monasterios e iglesias con sus pertenencias, concretamente los de San Juan de Pitilla, la iglesia de Santa Cecilia de Pamplona y el monasterio de Zeia Zaarra. Cuando posteriormente los dominios de este último se convierten en lugares baldíos (uenit ad dessolationem istud monasterium), los campesinos de Eguillor los ocupan y cultivan durante mucho tiempo sin abonar diezmos ni otras cargas. El abad Raimundo presenta su querella repetidas veces ante el rey Sancho Ramírez y su hijo Pedro por esta ocupación tras haber encontrado el diploma que probaba la donación del Mayor al cenobio legerense ${ }^{68}$. Sin aludir a detalles del procedimiento judicial llevado a cabo, se precisa la sentencia ordenada por el rey Pedro, quien, tras la muerte de Sancho Ramírez, prescribe la devolución de los terrenos ocupados por los de Eguillor (imperando precepit recuperare) ${ }^{69}$. Con todo, los campesinos apelan a su misericordia y le solicitan el espacio ocupado para poder sobrevivir. Tras aceptar la petición, el rey ruega al abad que les ceda una mitad de la tierra ocupada así como parte del monte y bosque cercanos. Probablemente, el interés real se justifica por la necesidad de repoblar terrenos de montaña que habían quedado despoblados ${ }^{70}$. En cualquier caso, el acuerdo no resultó eficaz a largo plazo ya que tuvo que firmarse una nueva concordia en tiempos del abad Berengario unos 20 años más tarde ${ }^{71}$.

${ }^{67}$ Los episodios de Garde y Navarzato muestran dos ejemplos de resistencia campesina ante la imposición de nuevas costumbres que consideraban degradantes (Laliena 2012, p. 111).

${ }^{68}$ La donación aparece en DMLeire, 23, a. 1032.

${ }^{69}$ Con todo, el rey tarda en actuar. En este sentido Larrea considera que la ocupación de terrenos baldíos es un factor importante para explicar la articulación progresiva de formas de superioridad social en el seno del campesinado y, por otro lado, la intensificación de las condiciones de servilización (2006, p. 392; Laliena 2012, p. 59).

${ }^{70}$ Laliena señala que en el último cuarto del s. XI se perciben signos de malestar en el campesinado por la dificultad creciente para acceder a la tierra "mientras el número de seniores militarizados se incrementaba" (2012, pp. 105-106). En este caso la actuación real parece favorecer, en cierta medida, la petición de la comunidad aldeana.

${ }_{71}$ Véase DMLeire, 278 (a. 1121): "Concordavimus inter nos et vos cum de illis terris unde habuimus discordia... habeamus nos omnem medietatem et uos aliam medietatem sine mala 
Un diploma datado en 1121 contiene el único testimonio en nuestra documentación del empleo de un duelo judicial para dirimir una controversia entre dos comunidades. El texto se inicia sin más preámbulos con la constatación del juicio que tuvo lugar entre los vecinos de Mendavia y Villamezquina por los límites de sus respectivas villas (CDIrache, 105). El abad de Irache había encomendado Mendavia a García López de Exaverri pero a causa de los enfrentamientos entre ambas villas, el abad solicitó llevar el hecho a juicio ante el rey y los seniores terre en Lizagorría. La sentencia judicial estableció que se dirimieran las diferencias a través de un duelo entre uno de Mendavia y otro de Villamezquina. Firmaron el acuerdo los mandatarios de las dos villas (acceperunt plaztum) y designaron a dos hombres para la lucha aunque, finalmente, por mediación del conde Sancho de Pamplona se llegó a una convenientia que evitó el duelo: el conde recorrió los términos de ambas villas colocando piedras para señalar su demarcación ${ }^{72}$. Esta práctica del duelo personal se constata también en un diploma de 1097 del Becerro Galicano en el que se relata el conflicto que enfrentó a los vecinos de Coja con los de Tobía y Matute por el uso de los montes y pastos que rodeaban sus villas. El diploma recoge únicamente los juramentos prestados por los representantes de las comunidades enfrentadas, la falta de acuerdo y el duelo final, que ganó el representante de $\mathrm{Coja}^{73}$.

\section{CONFLICTOS SIN INTERVENCIÓN REAL}

Este tipo de enfrentamientos corresponden a asuntos relativos a la jurisdicción del monasterio o del episcopado que se solventan por medio de una convenientia ventajosa para ambas partes sin necesidad de recurrir al arbitraje real. Al igual que en los casos anteriores, la existencia de fidelidades

uoce omnibus diebus in eternum".

72 "Sed cum pergere cepissent, ipsi de Uilla Mesquina ante iuramentum cum pugile et pedone suo dimiserunt ad ipsos de Mendauia de ipso ponte de Mendauia usque ad Sanctam Mariam, ecclesia intus stando, et usque ad Penas Pardas, contra riuum qui uocatur Egoncielo, et dederunt inde, et sic iurarunt. In crastinum autem illis in campum egressis, aduenit dompnus Sancius, comes de Pampilona, et nitebatur cum reliquis superuenientibus senioribus ut absque bello conuenirent se. Uarius enim est euentus bellorum". Esta última frase puede considerarse como un comentario breve del escriba con el que expresa el argumento principal del conde para proponer un acuerdo pacífico como alternativa al duelo.

73 "Et iuravit ex parte Tuvia et Matute Enneco Dominico de Matute in Sancto Martino de Castiello. Et dixit ita: «iuro quia vos de Colia de die debetis pascere et nocte a domos vestras revertere, et cabanna in montibus non debetis ponere». E ille alius, Blasco Sarrazin de Colia, iurans dixit «absit. Sed de illo rivuo de Tuvia unde nascet usque ad Naiela flumen, vicinos sumus in montibus et erbis et defesis de ista parte de aqua, et ponemus cabannas nostras latus aqua ex nostra parte, et pascimus per omnes montes, et nocte revertimur ad cabannas». Et fuit litis in Campastro, et fuit victus et superatus illo de Matute, Enneco Dominicoz". 
vasalláticas condiciona decisivamente el curso de los conflictos. El procedimiento es también idéntico: si la autoridad abacial no resuelve el conflicto, se recurre generalmente a la actuación de un iudex, que se encarga de convocar un juicio público, ejercer de mediador en el proceso y nombrar testigos para garantizar el cumplimiento del acuerdo.

Un caso ilustrativo es el episodio narrado en DMLeire, 104. El diploma se inicia con la descripción de una especie de asalto contra el término de Villatuerta conducido por el abad Bermudo de Irache, el señor García Sanz de San Esteban y los vecinos de Echávarri y Oteiza. El abad de Leire, que relata en primera persona los hechos, subraya la intención de los atacantes y la violencia de la irrupción ${ }^{74}$. Ambos bandos compuestos por los abades de Irache y Leire y sendos grupos de seniores y vecinos, celebran un "juicio", una asamblea señorial en la que tratan de zanjar el conflicto mediante un acuerdo: $h a-$ buimus grande iudicium et post iudicium placuit illis ut iurarent duo seniores de Villatorta ... et de uicinis similiter duos ${ }^{75}$. Se acuerda que los señores y vecinos elegidos como representantes presten juramento. Sin embargo, llegado el momento, los seniores de Villatuerta se niegan a hacerlo. El escriba expone en estilo directo las palabras desafiantes con las que rechazan el juramento: nos non iurabimus si partem non debemus habere in illo termino. Vistas las pretensiones señoriales, el conflicto se resuelve con un pacto: los seniores implicados en el acuerdo reciben una parte del término de Uillatuerta y el abad legerense termina el relato aludiendo a los reproches que se le pudieran hacer por haber cedido a la petición: si no lo hubiera hecho, habría perdido todo el término disputado ${ }^{76}$. El comentario tiene como fin justificar por parte del abad, que ha actuado en representación del monasterio, la cesión de parte de sus tierras: el pulso entre intereses señoriales y monásticos se salda con un reparto territorial que evita violencias mayores. El aspecto más llamativo de este episodio es nuevamente el modo en que la red de fidelidades e intereses señoriales condiciona el desenlace del conflicto y cómo los señores podían manipular los mecanismos jurídicos para favorecer sus intereses: el rechazo de los seniores del bando legerense a pronunciar el juramento si no lograban un resultado ventajoso con el acuerdo refleja la rivalidad existente en el interior de los propios dominios monásticos entre abades y señores dependientes en principio de la jurisdicción monástica. Cabe señalar también que el escriba

\footnotetext{
74 "Per forcia uoluerunt tollere nostrum terminum et facto consilio, uenerunt et intrauerunt in termino et ruperunt quantum uoluerunt sine nostro sciente et sine nostra uoluntate".

${ }^{75}$ La expresión "habuimus grande iudicium" sugiere un debate intenso entre las partes enfrentadas.

76 "Et si aliquis dixerit quod non fecimus bene istam causam, non reputet mihi quia si ita non faceremus, omnino perderemus illum terminum".
} 
muestra especial interés en recoger en estilo directo las palabras de los nobles que se encaran con el abad para probar la gravedad de la amenaza y justificar la cesión del abad.

Los enfrentamientos podían solucionarse también sin recurrir a un juicio en sentido estricto tal como se constata en DMLeire, $223^{77}$ o DMLeire, 219 (a. 1108). En este último diploma se relatan las continuas querellas planteadas al cenobio por los hermanos Fortún y Lope Semenones de Artieda a propósito de un palacio en Undués, recibido en usufructo por la madre de ambos pero que era propiedad del monasterio. Por otro lado, ambos hermanos reivindican también su parte en el monasterio de Igal, donado por Sancho Ramírez al cenobio legerense, y que había disfrutado como tenencia real el padre de ambos ${ }^{78}$. Tras un intercambio de reclamaciones y fianzas, y sin mediar juicio alguno, se restablece la paz entre el abad Raimundo y los hermanos por medio de un acuerdo (postea uero concordatum est inter nos et fecimus pacem $)^{79}$. A cambio de la renuncia a las propiedades citadas, el cenobio dona a los hermanos un mulo valorado en 150 sólidos. Aunque en un primer momento el acuerdo parece efectivo, dos años más tarde la continuidad de las desavenencias hace precisa la redacción de un nuevo diploma de donación (DMLeire, 232) en el que Fortunio Semenones reconoce la maldad de su actuación:

Ego predictus senior Fortun Semenones post multum temporis querelaui et pignoraui et multas malas contrarietates feci ad predictum abbatem et ad monachos... Nunc penitet me fecisse male contra Deum ${ }^{80}$.

En esta ocasión, la solución definitiva se presenta en el diploma como un acto de arrepentimiento cuya penitencia consiste en la devolución

77 Se trata de una carta donationis en la que el abad entrega a doña Toda dos piezas de terreno en nombre de la amistad y la vinculación que existía entre ambas partes desde antiguo ("propter societatem et bonam amicitiam"). Sin embargo, al término de las disposiciones se comprueba que tal donación es, en realidad, un trueque de propiedades cuyo objetivo es poner fin a una serie de "querimonias" presentadas por doña Toda ante Leire.

${ }^{78}$ Los hermanos Fortún y Lope Jiménez habían retenido como heredades en propiedad el palacio de Undués y el monasterio de Igal: el primero, donado en usufructo a su madre por un tío abuelo, debía pasar a ser propiedad de Leire tras la muerte de aquella y el segundo, otorgado como tenencia al padre de ambos por el rey Sancho Ramírez, había sido donado anteriormente por el rey a Leire.

${ }^{79}$ La solución en el caso del monasterio de Igal es confirmar su propiedad a Leire y ordenar a los hermanos el abandono de la misma ("definitio"): "confirmauit ilam donationem et posuit fermes". Cabe señalar que la mención del tipo documental recoge las acciones en las que se plasma el acuerdo: "Hec est carta definitionis, donationis siue euacuationis".

${ }^{80}$ Queremos destacar que en estos diplomas el término "pignorare" parece equivaler en ocasiones a "querelare". De hecho, su utilización como quasi sinónimo en la expresión "querelaui et pignoraui" en este diploma y en otros así lo sugiere. 
definitiva al monasterio de los bienes ocupados. Aunque ambos relatos los narran en primera persona los hermanos citados, es evidente que el escriba transfiere a los mismos la perspectiva ideológica legerense: los conatos de rebeldía señorial contra el monasterio se presentan como maldades cometidas contra Dios y las "donaciones" como medios de reparación. El reconocimiento de los querellantes de haber actuado con maldad podía ser presentado por los escribas monásticos como un acto instigado por el diablo, es decir, como una impiedad que debía ser reparada ${ }^{81}$.

Con todo, los acuerdos de carácter pragmático impulsados por el deseo de salvaguardar fidelidades vasalláticas se incumplían con facilidad si no iban acompañados de la celebración de un juicio público, tal como lo prueban las discordias surgidas entre Aznar Garcés de Mendinueta y el monasterio de Leire (DMLeire, 142). El tal Aznar y su mujer habían presentado su queja al abad Raimundo por la muerte de un caballo y la sustracción de los aparejos del mismo en la jurisdicción del monasterio. Tras solicitar garantías en repetidas ocasiones para compensar la pérdida (pignoraverunt abbatem propter istam causam), finalmente renuncian a un posible pleito (ingenuaverunt ei istum pleitum). Sin embargo, las desavenencias entre ambas partes persisten por diversos motivos ${ }^{82}$ y no cesan hasta que se celebra un juicio tras el cual se le prescribe a Aznar Garcés el pago de una multa monetaria y entregas en especie. Además, por difamar a un monje et alia multa mala, pierde la villa de Villatuerta de la que era tenente per manus abbati. El texto precisa también que posteriormente el senior Aznar López logró concertar una convenientia a raíz de la cual el abad perdonó al encausado el pago de la multa. A pesar del acuerdo y del nombramiento de un fiador, Aznar Garcés incumple de nuevo

${ }^{81}$ Así se observa también en BG, 3 (a. 1050) donde se relata el enfrentamiento de los vecinos de Madriz contra el monasterio de San Millán. La existencia del conflicto ("discidium") se presenta como una maldad instigada por el diablo que se resuelve gracias a la intervención real a través de un acuerdo: los campesinos, seducidos por la maldad ("male suasi atque iurgati"), habrían promovido un pleito que terminó en un acuerdo ("concordia") aceptado por unanimidad por los miembros de la asamblea reunida para solventar el conflicto. El rey prescribe las órdenes precisas en que se concreta la sentencia: delimitación del término que los vecinos deben cultivar para el monasterio y derechos para pastos y leña en los territorios mencionados para beneficio de los monjes. En este documento interesa subrayar sobre todo la función pacificadora del rey que consigue restaurar la concordia, es decir, el orden feudal, y asegurar los privilegios señoriales del monasterio ("Nullus hominis nevo seducti sed divini spiritus afluentia animati, et pro nostrorum expiatione delicti, et pro adipiscenda suffragia patroni beatissimi Emiliani... concordes atque unanimes illud conterimus discidium").

${ }^{82}$ Aznar y su mujer negaron haber recibido los aparejos y pidieron nuevamente una compensación por ello y por el vino que el abad había tomado de una villa de Leire que la esposa de Aznar poseía en usufructo en Sansoain. El abad por otro lado, presenta sus quejas porque no recibía ningún servicium y porque además en la tenencia otorgada a Aznar en Villatorta, este había retenido por la fuerza la cantidad de trigo estipulada como censo. Fue multado por ello y también por difamar al monje Poncio. 
lo acordado (placitum negavit) e intenta recuperar lo perdido. La solución definitiva se consigue mediante la ratificación del acuerdo por parte de Aznar y el nombramiento público del garante citado ante numerosos testigos en Villatuerta. El relato textual subraya dos aspectos: por un lado, los persistentes actos de rebeldía cometidos por Aznar Garcés contra el monasterio con el que mantenía una relación vasallática ${ }^{83} \mathrm{y}$, por otro, el incumplimiento de los compromisos derivados del proceso judicial. Aunque no se ofrecen detalles de las diversas fases de dicho proceso, parece claro que en un primer momento el abad gestiona el conflicto como un asunto particular relativo a su jurisdicción. Sin embargo, las dos partes tienen que recurrir posteriormente a un juicio y al acuerdo de una convenientia más ventajosa para el encausado. Del relato se deduce que el reconocimiento público de la sentencia emitida y el nombramiento de numerosos testigos (recognovit ipsum placitum totum et confirmavit ipsum firmem coram multis testibus) es lo que permite zanjar el conflicto y restablecer la concordia entre las partes: finalmente, Aznar Garcés y su esposa confirman el documento cum bona voluntate. En el relato se percibe la complejidad de las relaciones de dependencia así como la parcialidad de la narración: el escriba selecciona la mención de ciertos hechos presentados como maldades y los acuerdos que incluyen algún tipo de perdón por parte del monasterio. Asimismo, la importancia del reconocimiento público y el nombramiento de numerosos testigos adquieren una relevancia especial.

En este tipo de negociaciones sin mediación real, la prestación del juramento es también un elemento decisivo para ratificar el acuerdo ante el abad y los testigos. En DMLeire, 195 se relata un conflicto entre Leire y García López, de quien se dice que había usurpado una casa con sus tierras a los mezquinos que el monasterio tenía en la villa de Aldunat. Ante la acusación del abad, García López lo niega todo y tiene lugar un juicio. Tras reconocer la verdad defendida por el monasterio, el acusado, acompañado de sus amigos (cum amicis suis) presenta una petición al abad: disponer de la heredad usurpada con ingenuidad en lo relativo al censo y al fosado, pero ofreciendo tributos en forma de servicios de trabajo con el compromiso de que, a su muerte todos sus bienes pasaran a ser íntegramente propiedad del monasterio. El acuerdo se ratifica designando dos fiadores ante el abad y la comunidad ${ }^{84}$. Este diploma

${ }^{83}$ Se afirma que aquel había recibido la villa de Villatorta "per manus abbati" y que se encontraba "in amicicia et in fidelitate eius".

84 "Rogauit... prescriptum abbatem ut dimisisset ei ingenuam ipsam hereditatem in diebus suis sine censu et sine fossataria set in laboribus agrorum et uinearum adiuuasset sicut ceteri homines ipsius uille". La buena "voluntad" del cenobio se refleja en la cláusula que cierra el documento: si su esposa muere antes, el susodicho podrá ingresar en la comunidad monástica con todos sus bienes y a cambio Leire le proveerá de alimento, vestido y todo lo que precise: "si autem euenerit ut post mortem uxoris sue habeat uoluntatem et uoluerit uenire ad nos cum 
presenta las características de un conflicto vertical: tras prestar juramento y reconocer la ocupación de las tierras, implora su usufructo a cambios de prestaciones en trabajo. En realidad, la causa que originaba ocupaciones de este tipo y posteriores pleitos por parte de pequeños propietarios libres era el endeudamiento, tal como se constata también en DMLeire, $259^{85}$.

Un caso de mala gestión es el origen del pleito narrado en CDCPamplona, 132 (a. 1119) que, por otro lado, pone en evidencia nuevamente la prioridad de la perspectiva pragmática basada en los pactos sobre la propiamente legal. El obispo Guillermo acusa a Bellitus, encargado de la iglesia de San Martín de haber incurrido en un delito quadam leuitate seductus. Junto con el iusticia y varios sapientes viri, el obispo ordena ante todo el pueblo de Uncastillo su destitución. Aunque el acusado reconoce su culpa y entrega las llaves de la iglesia, el juez y los vecinos de Uncastillo solicitan que le sean entregadas de nuevo las llaves bajo ciertas condiciones. Al final del diploma se especifica que para recuperar el favor del obispo Bellitus pagó 400 sólidos $^{86}$. El relato de los hechos sugiere que tras el juicio, y a pesar de la culpabilidad del acusado, se pactó una solución económicamente ventajosa para el obispado atendiendo la petición de la comunidad de Uncastillo ${ }^{87}$.

Avanzado ya el siglo XII, el recurso a las convenientias continuaba siendo el medio habitual de solucionar los conflictos entre particulares y entidades religiosas o señoriales. En CDCPamplona, 359 se relata el pleito y posterior acuerdo entre Sancho, canónigo de Pamplona y el señor García Bláskiz sobre la heredad de Solchaga donada ex integro al Cabildo por la esposa de Auriol Sánchez. Aunque el diploma está deteriorado en parte se puede leer con claridad que el acuerdo y la cesión correspondiente se plantean por sugerencia de varios señores, miembros de la asamblea judicial que se habría constituido como era común para la resolución de pleitos (rogatu et suasu senioris... aliorumque sociorum). El canónigo acepta el pacto propuesto y con él, la cesión de varias propiedades a la vez que García Blaskiz se compromete

omni possessione et radice sua, recipiamus eum et habeat uictum et uestitum et necesaria corporis sui".

${ }^{85}$ Se narra el acuerdo pactado entre el monasterio y Lope Jiménez, yerno de Lope Sanz de Lusia quien, embargado por las deudas se había encomendado al monasterio. El abad Raimundo firma una convenientia con Lope y su esposa tras consultar a los "boni homines" de Lusia y les cede parte de los bienes heredados de Lope Sanz, bienes que, en rigor, habían sido legados a Leire: impera de nuevo la voluntad de evitar un conflicto de mayor calado.

86 "Ad recuperandam episcopi dilectionem dedit Bellito CCCC solidos".

87 "Tandem rogatu iusticie qui aderat et senioris Fortunionii Sancii et uicinorum Unicastri reddidit ei clause sub tali condicione, ut siue in morte siue in uita qualibet ora dompnus episcopus uellet, clause reciperet". 
a detener cualquier ataque a la heredad disputada por parte de los suyos ${ }^{88}$. El diploma no solo concreta las condiciones del acuerdo sino que precisa también la obligatoriedad de darlo a conocer a los parientes del acusado para que muestren su conformidad o su rechazo y el canónigo pueda obrar así en consecuencia. Es llamativo en este caso el modo como se relata la concreción de lo pactado: García Blásquiz acude hasta el canónigo Sancho a solicitar las tierras acordadas pero este desconfía de posibles engaños por parte de los hombres de aquel ${ }^{89}$. Por ello recurre al señor que había propuesto el pacto para solicitar el nombramiento de fiadores que garanticen el cumplimiento del acuerdo. La posibilidad de manipular o incumplir los pactos evidencia la fragilidad de un mecanismo de resolución que no está sustentado en un cuerpo legislativo concreto.

\section{CONCLUSIONES}

Como se ha indicado en el inicio del trabajo, en el corpus documental analizado no se conservan relatos de pleitos de época altomedieval. Los diplomas comentados reflejan mayoritariamente el marco social y político de la segunda mitad del s. XI y primera mitad del XII, un período en que el proceso de señorialización se había consolidado plenamente. A partir de la casuística descrita cabe señalar que los conflictos más numerosos son los generados en torno a una donación, en especial, tras una donación testamentaria: este tipo de situaciones constituyen el $47 \%$ de los casos analizados. La inexistencia de escritos que ratificaran la donación de un término, la manipulación o incluso falsificación de diplomas o los conflictos jurisdiccionales generados tras una donación entre la entidad receptora de la misma y los propietarios o tenentes de los bienes donados constituyen la casuística más común. Los conflictos restantes correspondes a casos de ocupación o usurpación de tierras (un 17 \%), el rechazo al pago de diezmos y realización de prestaciones $(29,5 \%)$ y casos aislados de endeudamiento o reivindicación de infanzonía. Por otro lado, la mediación real desempeña un papel importante en la resolución de conflictos si se tiene en cuenta que aparece en un $44,5 \%$ de los conflictos analizados. En cualquier caso, los pleitos con arbitraje real disminuyen de forma notoria desde comienzos del siglo XII a medida que se delega dicha función en representantes reales encargados de la impartición de justicia. Hay que tener en

\footnotetext{
88 "Hoc ipsemet addens ut omnes... super hoc placito insurgentes siue filios siue parentes seu extraneos uoce senioris Aureoli Santii refrenet ne quid illius honoris ulterius a nobis exigent".

89 "Ego autem timens laqueum horum indigenarum adii seniorem... cuius consilio feceramus supradictam conuenientiam".
} 
cuenta, además, que en conflictos pertenecientes a la jurisdicción monástica o episcopal no intervenían instancias superiores sino en confrontaciones persistentes en el tiempo. También se constata que la importancia de la memoria colectiva representada por el testimonio de los ancianos ocupa un lugar relevante en los pleitos relativos a la ocupación de tierras y delimitación de lindes. En este sentido, cabe recordar que la explotación indirecta de los dominios monásticos a través de diferentes tipos de servidumbre, se combina en Navarra y Aragón con la concesión de unidades dominiales en prestimonio u honor a miembros de la élite señorial desde finales del s. $\mathrm{XI}^{90}$. Estas donaciones y tenencias podían dar lugar a diversos conflictos jurisdiccionales, sobre todo, cuando los beneficiarios intentaban trasmitir hereditariamente estos bienes. Tal circunstancia explica que el número de enfrentamientos basados en donaciones y testamentos constituya casi la mitad de los diplomas examinados. Por último, es interesante subrayar que las situaciones en que los conflictos son generados por la actuación de comunidades constituyen un $21 \%$ del total de diplomas analizados: los procesos de rebelión en Garde, Navarzato, Eguillor o Villatuerta reflejan la presión ejercida por grupos de campesinos reacios a aceptar la servidumbre señorial que las entidades religiosas pretenden imponer con la anuencia real.

Además de la tipología de los pleitos, el análisis nos ha permitido comprobar que el relato de los hechos refleja, a pesar de la concisión narrativa, la intencionalidad que anima a las entidades emisoras. La perspectiva ideológica condiciona tanto la selección de los hechos relatados como la imagen que se ofrece del rey, del abad o del obispo como agentes mediadores y, en general, de las partes implicadas en los conflictos. Con excepción de los pleitos relativos al establecimiento de lindes, los monasterios y espacios religiosos se presentan como foros sagrados donde se imparte justicia, una justicia cuya finalidad es evidenciar la verdad y restaurar la concordia en un marco ritualizado y simbólico a través de la mediación real o de la de un iudex. La restauración de la paz implica, por otro lado, mantener el orden feudal establecido y proteger a las entidades religiosas que dispensan las correspondientes recompensas espirituales.

En los conflictos en que interviene el rey, el procedimiento judicial sirve, entre otros objetivos, para subrayar la actuación de aquel como princeps cristiano y mostrar su complicidad con la élite eclesial. El rey imparte justicia apoyado en la autoridad superior que representa y la clemencia cristiana que se le atribuye. No se advierten, sin embargo, atisbos de la actividad legisladora que se le adjudicará posteriormente y que están relacionados con la consolidación de su autoridad sobre la élite nobiliaria y eclesial del reino.

${ }^{90}$ Fortún 2002, p. 135. 
En cualquier caso, bajo la retórica de la verdad y la restauración ${ }^{91}$, se perciben los móviles ideológicos y materiales que condicionan realmente los procesos. La utilización de tópicos basados en la relación maldad-castigo, perdón-reparación o caridad-recompensa espiritual para justificar el origen y el desenlace de los procesos es un reflejo de la perspectiva religiosa adoptada por la entidad emisora. El factor que influye más decisivamente en la mediación y resolución de conflictos es la existencia de relaciones vasalláticas entre los miembros de la élite dominante (ya sean el rey, el obispo o entidades religiosas poderosas) y señores particulares: el interés por salvaguardar la relación de fidelidad existente entre las partes implicadas explica el recurso a negociaciones y acuerdos que van más allá del mero establecimiento de culpas y responsabilidades pecuniarias. La proposición de convenientias por parte de los señores que median en los conflictos se constituye así en un mecanismo pragmático que se aplica durante todo el período abordado, sustentado a menudo en tópicos y argumentos de carácter religioso que no ocultan la voluntad de mantener el poder y el control señorial sobre personas y bienes. Así, por ejemplo, el abad o el obispo son capaces de perdonar las multas pecuniarias derivadas de un juicio y ceder parte de los términos disputados a cambio de la entrega de censos o tributos en especie. Bajo la imagen de piedad y clemencia cristianas subyace, en realidad, el deseo de preservar las fidelidades señoriales.

Podría decirse, por tanto, que a pesar de la pervivencia de la mecánica judicial tradicional basada en la preeminencia de la autoridad real o la mediación del iudex designado, las soluciones pragmáticas se imponen sobre los procedimientos judiciales propiamente dichos. Hasta mediados del siglo XII, la celebración de iudicia hace referencia a la constitución de asambleas de nobles o principales presididos por el rey, el abad/obispo o un representante real pero no puede afirmarse que el denominado iudex sea más que un mediador. Tampoco la asamblea en cuestión está constituida por miembros designados específicamente para la impartición de justicia: son los representantes de la élite dominante los que se encargan de la gestión de los conflictos y actúan como promotores de los acuerdos. En general, la aplicación de normativas jurídicas recopiladas por escrito y su gestión a través de cargos específicos y procedimientos judiciales se observa con precisión en las concesiones de fueros, códigos normativos que regulan la convivencia en villas y comunidades y que sistematizan por escrito costumbres mucho más antiguas. Entretanto, los pactos regulados por mediadores a través de cesiones mutuas y acuerdos ventajosos para los señores implicados se constituyen como solución mayoritaria si bien

${ }^{91}$ I. Alfonso subraya la importancia de las asambleas judiciales como espacios de legitimización real a través de discursos que insisten en la restauración de la justicia y la defensa retórica de la verdad (1997, pp. 78-79). 
precisan ser publicitados y garantizados por testigos y fiadores. En resumen, fuera del ámbito canónico, el procedimiento judicial no constituye aún un mecanismo profesionalizado y riguroso, asentado en un cuerpo legal.

\section{FUENTES PRIMARIAS}

Becerro Galicano digital [en línea], http:/www.ehu.es/galicano/ [consulta: 25/05/2020].

Goñi Gaztambide, José (1997), Colección Diplomática de la Catedral de Pamplona I (829-1243), Pamplona, Gobierno de Navarra.

Lacarra, José M. a (1965), Colección Diplomática de Irache. Vol. I (958-1222), Zaragoza, Ediciones Universidad de Navarra.

Lema Pueyo, José A. (1990), Colección Diplomática de Alfonso I de Aragón y Pamplona (1104-1134), San Sebastián, Eusko Ikaskuntza.

Martín Duque, Ángel J. (1983), Documentación Medieval de Leire (siglos IX a XII), Pamplona, Gobierno de Navarra.

Ubieto Arteta, Antonio (1962), Cartulario de San Juan de la Peña, Valencia, Anubar.

\section{BIBLIOGRAFÍA CITADA}

Adachi, Takashi (2007), Documents of Dispute Settlement in Eleventh-century Aragon and Navarra. Kins's tribunal and Compromise, "Imago Temporis. Medium Aevum" 1, pp. 71-85.

Alfonso, Isabel (1997), Litigios por la tierra y "malfetrías" entre la nobleza medieval castellano-leonesa, "Hispania. Revista española de Historia” 57/197, pp. 917-955.

Alfonso, Isabel; Escalona, Julio; Kennedy, Hugh (eds.) (2004), Building legitimacy: Political Discourses and Forms of Legitimation in Medieval Societies, Leiden, Brill.

Alfonso, Isabel (2004), Judicial rhetoric and political legitimation in medieval Leon-Castille, en Alfonso, Isabel; Escalona, Julio; Kennedy, Hugh (eds.), Building Legitimacy: Political Discourses and Forms of Legitimation in Medieval Societies, Leiden, Brill, pp. 51-88.

Andrade Cernadas, José M. ${ }^{\text {a }}$ (2012), La voz de los ancianos. La intervención de los viejos en los pleitos y disputas en la Galicia medieval, "Hispania. Revista Española de Historia" 72/ 240, pp. 11-34.

Billoré, M.; Mathieu, I.; Avignon, C. (2012), La justice dans la France médiévale: VIII ${ }^{e}-X I I^{e}$ siècle, París, Armand Colin. 
Bossy, John (ed.) (1983), Disputes et Settlements: Law and Human Relations in the West, Cambridge.

Brown, W. C.; Górecki, C. (eds.) (2003), Conflict in Medieval Europe: Changing Perspectives on Society and Culture, Hampshire, Routledge.

Calderón Ortega, J. M. (1999), La justicia en Castilla y León durante la Edad Media, en La Administración de justicia en la Historia de España. Actas de las III Jornadas de Castilla-La Mancha sobre investigación en archivos, Guadalajara, Junta de Comunidades de Castilla-La Mancha, pp. 21-38.

Collins, Roger, (1986), Visigothic law and regional custom in disputes in early medieval Spain, en Davis, Wendy; Fouracre, Paul (eds.), The Settlement of disputes in Early Medieval Europe, Cambridge, Cambridge University Press, pp. 85-104.

Davies, Wendy; Fouracre, Paul (eds.) (1986), The Stettlement of Disputes in Early Middle Ages, Cambridge, Cambridge University Press.

Davies, Wendy (2007), Lordship and Community: Northern Spain on the Eve of the Year 1000, "Past \& Present" 195/2, pp. 18-33.

Davies, Wendy, (2016), Windows on Justice in Northern Iberia, 800-1000, Oxford - Nueva York, Routledge.

Davies, Wendy, (2020), Christian Spain and Portugal in the Early Middle Ages: Texts and Societies, Nueva York, Routledge.

Díaz de Durana, Ramón (2016), La otra nobleza, la hidalguía, en Discurso, memoria y representación. La nobleza peninsular en la Baja Edad Media. Actas de la XLII Semana de Estudios Medievales de Estella-Lizarra. 21 al 24 de julio de 2015, Pamplona, Gobierno de Navarra, pp. 333-376.

Du Cange, Charles du Fresne, et al. (1883-1887), Glossarium mediae et infimae latinitatis, Niort, L. Favre [en línea], http://ducange.enc. sorbonne.fr/ [consulta: 5/05/2020].

Fortún, Luis Javier (1993), Leire, un señorío monástico en Navarra (siglos IX-XIX), Pamplona, Gobierno de Navarra.

Fortún, Luis Javier (2005), Monjes y obispos: la Iglesia en el reinado de García Sánchez III el de Nájera, en Iglesia, José I. de la (coord.), García Sánchez III el de Nájera: un rey y un reino en la Europa del siglo XI, Logroño, Gobierno de La Rioja, pp. 191-252.

Geary, Patrick (1986), Vivre en conflit dans une France sans État: typologie des mécanismes de règlement des conflits (1050-1200), "Annales: Économies, Sociétés, civilisations" 42, pp. 1107-1133.

Goñi Gaztambide, J. (1979), Historia de los obispos de Pamplona (s. IV-XIII), vol. I, Pamplona, Servicio de Publicaciones de la Universidad de Navarra.

Guijarro González, Susana (1988), La terminología que define los grupos sociales a través de la documentación medieval de San Salvador de Leire (siglos IX-XII), "Príncipe de Viana" 49/183, pp. 97-112. 
Hudson, John (1997), La interpretación de disputas y resoluciones: el caso inglés c. 1066-1135, "Hispania. Revista Española de Historia" 57/197, pp. 885-916.

Laliena, Carlos (1998), Expansión territorial, ruptura social y desarrollo de la sociedad feudal en el Valle del Ebro, 1080-1120, en Utrilla Utrilla, Juan F.; Laliena Corbera, Carlos (eds.), De Toledo a Huesca. Sociedades medievales en transición a finales del siglo XI (1080-1100), Zaragoza, Institución Fernando el Católico, pp. 199-227.

Laliena, Carlos (1996), La formación del estado feudal: Aragón y Navarra en la época de Pedro I, Huesca, Instituto de Estudios Altoaragoneses.

Laliena, Carlos (2012), Siervos medievales de Aragón y Navarra en los SS. XIXII, Zaragoza, Prensas de la Universidad de Zaragoza.

Larrea, Juan José (1998), La Navarre du IV au XII siècle. Peuplement et société, París - Bruselas, De Boeck Université.

Larrea, Juan José (2006), La condición del campesinado navarro-aragonés entre los siglos IX y XII: una revisión crítica, "En la España Medieval" 29, pp. 383-409.

Lohring García, M. I. (1989), La expansión de la servidumbre en el reino de Navarra a mediados del siglo XI: el ejemplo de Terrero, "En la España Medieval" 12, pp. 45-61.

Martín Duque, Ángel J. (2002), Nobleza navarra altomedieval, "Príncipe de Viana" 63/227, pp. 667-690.

Martín Prieto, Pablo (2016), Justicia medieval. Introducción a una mesa redonda y sus resultados, "De Medio Aevo" 10/2, pp. 1-8.

Monsalvo, José M. a (2016), Los conflictos sociales en la Edad Media, Madrid, Editorial Síntesis.

Pérez, Mariel (2015), Aristocracia, monasterios y conflictos por la tierra. Reforma eclesiástica y relaciones sociales en León (siglos XI-XIII), "Bulletin du Centre d'Études Médiévales" 19/1, DOI: 10.4000/ cem.13899.

Salrach, Josep M. (1997), Prácticas judiciales, transformación social y acción política en Cataluña (siglos IX-XIII), "Hispania. Revista Española de Historia" 57/197, pp. 1009-1045.

Salrach, Josep M. (2001), Les modalités du règlement des conflits en Catalogne aux XI et XII siècles, en Le règlement des conflits au Moyen Âge. Actes du XXXI congrès de la Société des Historiens médiévistes de l'Enseignement Supérieur Public (SHMESP), París, Publications de la Sorbonne, pp. 117-134.

Salrach, Josep M.; Montagut i Estragués, Tomás de (2018), Justícia i resolució de conflictes a la Catalunya medieval, ss. IX-XI, Barcelona, Generalitat de Catalunya. 
SHMESP(ed.) (2001), Le règlement des conflits au Moyen Âge. Actes des XXXI congrès de la Société des Historiens médiévistes de l'Enseignement Supérieur Public (SHMESP), París, Publications de la Sorbonne.

Smail, Daniel (1997), Archivos de conocimiento y la cultura legal de la publicidad en la Marsella medieval, "Hispania. Revista española de historia" 57/197, pp. 1047-1077.

Tomás Faci, Guillermo (2015), Geografía de la población infanzona en Aragón (siglos XIII-XV), "Aragón en la Edad Media" 26, pp. 325-349.

Tomás Faci, Guillermo (2017), Las comunidades locales contra los infanzones. Conflictos en torno al estatuto jurídico en el Aragón rural hacia 1300, "Studia historica. Historia medieval" 35/1, pp. 49-71.

White, S. (1978), Pactum Legem vincit et Amor Iudicium: the Settlement of Disputes by Compromise in Eleventh Century Western France, "The American Journal of Legal History" 22, pp. 281-308.

Fecha de recepción del artículo: julio 2020

Fecha de aceptación y versión final: marzo 2021 
